\title{
SŁAWOMIR KUREK
}

Uniwersytet Pedagogiczny im. Komisji Edukacji Narodowej w Krakowie Instytut Geografii

Zakład Geografii Społeczno-Ekonomicznej

\section{PRZESTRZENNE ZRÓŻNICOWANIE PRZEMIAN DEMOgRAFiCZNYCH W POLSCE W LATACH 2002-2011 \\ SPATIAL PATTERN OF DEMOGRAPHIC CHANGE IN POLAND IN THE YEARS 2002-2011}

Artykuł wpłynął do redakcji 03.02.2014 r.; po recenzjach zaakceptowany 27.02.2014 r.

KUREK S., 2014, Przestrzenne zróżnicowanie przemian demograficznych w Polsce w latach 2002-2011 [w:] Klima E. (red.), Ludność, Mieszkalnictwo, Ustugi - w 70. rocznice urodzin Profesora Jerzego Dzieciuchowicza. Population, Housing, Services - $70^{\text {th }}$ Anniversary of Professor Jerzy Dzieciuchowicz, „Space-Society-Economy” 13, Department of Population and Services Studies, Wydawnictwo Uniwersytetu Łódzkiego, Łódź, s. 43-73.

/ISSN 1733-3180/

Dr hab. Sławomir Kurek, prof. UP, Uniwersytet Pedagogiczny w Krakowie, Instytut Geografii, Zakład Geografii Społeczno-Ekonomicznej, ul.Podchorążych 2,30-084 Kraków; e-mail: sgkurek@up.krakow.pl

\section{STRESZCZENIE}

Współczesne procesy demograficzne w Polsce można rozpatrywać w kontekście procesów suburbanizacji zmierzających do koncentracji ludności w zewnętrznej części obszarów metropolitalnych oraz w aspekcie teorii drugiego przejścia demograficznego, prowadzących do spadku poziomu dzietności poniżej granicy zastępowalności pokoleń. Celem niniejszego opracowania jest ukazanie współczesnych przemian demograficznych w Polsce w ujęciu przestrzennym na początku XXI wieku, w szczególności w świetle zmian pomiędzy dwoma narodowymi spisami powszechnymi w Polsce (w 2002 i 2011 roku), uzupełnione statystyką bieżącą z Banku 
Danych Lokalnych GUS. Przeanalizo-wano takie zagadnienia jak: dynamika zaludnienia, przyrost naturalny, saldo migracji oraz zmiany $\mathrm{w}$ strukturze wieku ludności. Przeprowadzono typologię Webba dla powiatów oraz typologię struktury wieku ludności metodą typografów. Analiza wykazała dużą polaryzację przestrzenną przebiegających procesów demograficznych pomiędzy obszarami metropolitalnymi a peryferyjnymi.

SŁOWA KLUCZOWE: zmiany demograficzne, migracje, przyrost naturalny, struktura wieku, prawidłowości przestrzenne, suburbanizacja, Polska

\subsection{WPROWADZENIE}

Na przełomie XX i XXI wieku w Polsce dokonały się znaczące przemiany demograficzne, niespotykane w powojennej historii. Polegały one głównie na osłabieniu dynamiki demograficznej poprzez gwałtowny spadek natężenia urodzeń oraz, trudny do oszacowania, ubytek wędrówkowy ludności związany z emigracją zagraniczną po wejściu Polski do Unii Europejskiej. Konsekwencją tych przemian było zwiększenie poziomu starości demograficznej i przyspieszenie dynamiki starzenia się ludności. Wymienione zmiany demograficzne zachodziły z różnym natężeniem w różnych częściach kraju, dlatego ważne jest śledzenie zróżnicowania przestrzennego obserwowanych zjawisk i procesów, prowadzących do wykształcenia się układu centra (obszary metropolitalne) peryferia. Przyczyniły się do tego wewnętrzne przemieszczenia ludności pomiędzy miastami a obszarami wiejskimi oraz odmiennie przebiegające zachowania prokreacyjne w dużych miastach i na obszarach wiejskich. W zakresie migracji wewnętrznych od lat 90. zanotowano spadek natężenia napływu ludności do miast i zmianę głównego kierunku przemieszczeń ludności z wiejsko-miejskiego na miejsko-wiejski, który był związany z napływem do stref podmiejskich. Spadek natężenia urodzeń doprowadził do ubytku naturalnego ludności (głównie w dużych miastach) i rozprzestrzeniania się modelu rodziny małodzietnej z terenów zurbanizowanych na obszary wiejskie.

Współczesne procesy demograficzne w Polsce można rozpatrywać w kontekście procesów suburbanizacji zmierzających do koncentracji ludności w zewnętrznej części obszarów metropolitalnych (np. Dzieciuchowicz 1995; Jakóbczyk-Gryszkiewicz 1998, 2011; Zborowski 2005; Śleszyński 2006, 2012; Słodczyk 2011; Winiarczyk-Raźniak, Raźniak 2012) oraz w aspekcie teorii drugiego przejścia demograficznego, prowadzących do spadku poziomu dzietności poniżej granicy zastępowalności pokoleń (m.in. Kotowska 2008; Kurek 2012; Kurek, Lange 2013). Mianem suburbanizacji określa się zwykle w aspekcie ekonomicznym proces przepływu ludności, kapitału i podmiotów gospodarczych z rdzenia miejskiego do strefy zewnętrznej (Lisowski 2007) oraz w sensie społeczno-demograficznym jedną $\mathrm{z}$ faz w cyklu rozwoju regionu 
miejskiego (Van den Berg i in. 1982). Według tej koncepcji demograficznego cyklu życia miasta, w fazie suburbanizacji następuje spadek liczby ludności miasta centralnego $\mathrm{W}$ wyniku ubytku migracyjnego, natomiast zaludnia się intensywnie strefa podmiejska, charakteryzująca się dodatnim saldem migracji. Podłożem tej decentralizacji przestrzennej ludności jest wzrost zamożności mieszkańców, poziom renty gruntowej, wzrost świadomości ekologicznej, rozwój transportu i motoryzacji, dostępność kredytów itp. Z kolei przemiany związane $\mathrm{z}$ drugim przejściem demograficznym polegają na zmianie modelu rodziny wynikającego z rozwoju społeczeństw postindustrialnych oraz zmian norm obyczajowych np.: wzrost natężenia rozwodów, spadek liczby zawieranych małżeństw, wzrost średniego wieku rodzenia matek itp. (Van de Kaa 1987, 2003, 2004; Sobotka 2008).

Celem niniejszego opracowania jest przedstawienie przestrzennego zróżnicowania współczesnych przemian demograficznych w Polsce w ujęciu powiatów na początku XXI wieku, w latach 2002-2011. Opracowanie powstało na podstawie spisów powszechnych w 2002 i 2011 r. i uzupełnione jest statystyką bieżącą z Banku Danych Lokalnych GUS. Przeanalizowano zmiany zaludnienia w okresie międzyspisowym, współczynniki przyrostu naturalnego i salda migracji oraz zmiany $\mathrm{w}$ strukturze wieku ludności. Przeprowadzono typologię Webba dla powiatów oraz typologię struktury wieku ludności metodą typografów (Długosz 1996, 1998).

\subsection{ZMIANY W ZALUDNIENIU}

Według danych narodowych spisów powszechnych z 2002 i 2011 r., liczba ludności w Polsce w latach 2002-2011 wzrosła o 0,7\%, z 38230 tys. do 38501 tys. Zgodnie z metodologią NSP 2011, bezpośrednio ankietowanych było tylko 20\% mieszkańców Polski, natomiast informacje o pozostałych osobach zaczerpnięto z baz ewidencyjnych. Co prawda $20 \%$ ludności stanowi na tyle dużą próbę, aby szacować wyniki dla całej populacji, to jednak do różnego rodzaju analiz przestrzennych, zwłaszcza w mikroskali, może być ona niewystarczająca, gdyż wiele osób nie melduje się w miejscu zamieszkania. Na przykład w Warszawie liczbę osób niezameldowanych ocenia się maksymalnie na 25-30\% liczby ogólnego zaludnienia miasta, wykazywanej przez GUS (Lisowski 2007, s. 227), a według szacunków J. Bijaka i in. (2007, s. 68) liczba ludności tam faktycznie zamieszkałej jest o około 260 tys. większa. Niemniej jednak, ostatni spis objął nową kategorię ludności, tzw. ludności rezydencjonalnej, tj. stałych mieszkańców, z wyjątkiem osób przebywających poza miejscem zamieszkania przez okres co najmniej 12 miesięcy - bez względu na ich miejsce przebywania (w kraju czy za granicą) oraz osób mieszkających czasowo przez okres co najmniej 12 miesięcy, przybyłych z innego miejsca w kraju lub 
z zagranicy. W ten sposób, przynajmniej pośrednio, możemy wnioskować o natężeniu i przestrzennym zróżnicowaniu zagranicznej migracji czasowej po $2004 \mathrm{r}$. Biorąc pod uwagę podział na miasto i wieś w świetle wyników spisu z 2001 r. liczba ludności faktycznie zamieszkałej w miastach zmniejszyła się od 2002 r. o 204 tys. osób (z 61,8 do 60,2\% ogółu ludności), natomiast o 486 tys. zwiększyła się liczba mieszkańców wsi (z 38,2 do 39,8\%). Zmiany te były spowodowane $\mathrm{w}$ dużej mierze migracjami $\mathrm{z}$ dużych ośrodków miejskich na tereny otaczające, należące już do terenów administracyjnie wyodrębnianych jako obszary wiejskie. W układzie województw największy wzrost liczby ludności w okresie 2002-2011 zaznaczył się w województwie mazowieckim, małopolskim, pomorskim oraz wielkopolskim (łącznie o ponad 441 tys.), natomiast największy spadek w województwie śląskim, łódzkim i opolskim (ryc. 1). W miastach największy przyrost rzeczywisty ludności wystąpił w województwie mazowieckim (o 69 tys.), a następnie w podkarpackim (zaledwie o 29 tys.), zaś największy spadek ludności miejskiej dotyczył województwa śląskiego (150 tys.) oraz łódzkiego (76 tys.). Wśród mieszkańców wsi największy wzrost zanotowano w tych samych województwach co wśród ludności ogółem, zaś największy spadek w województwie opolskim i podlaskim (ryc. 2). W układzie powiatów największy wzrost zaludnienia zanotowały powiaty położone wokół dużych i średnich miast (np. piaseczyński - o 34\%, wrocławski - o 26\%, poznański i gdański - o 25\%). W 206 powiatach zanotowano wzrost liczby ludności, a w 173 - spadek (ryc. 3). Największy ubytek rzeczywisty w okresie międzyspisowym wystąpił w powiecie krasnostawskim (o 14\%), mieście Bytom (9\%), miastach: Gliwice i Łódź oraz powiecie grójeckim (po 8\%). Wśród ludności miejskiej największy wzrost wystąpił w powiecie tarnowskim (o 52\%), dąbrowskim (42\%), piotrkowskim (40\%) oraz rzeszowskim (38\%), ale na wysokie wartości przyrostu rzeczywistego w tych powiatach miały wpływ zmiany administracyjne (uzyskanie praw miejskich przez Boguchwałę w powiecie rzeszowskim, Wojnicz i Zakliczyn w powiecie tarnowskim, Szczucin w powiecie dąbrowskim oraz Wolbórz w powiecie piotrkowskim). W przypadku powiatów grodzkich, tylko w dziewięciu zanotowano wzrost zaludnienia ( $\mathrm{w}$ tym w Warszawie i Krakowie) natomiast w pozostałych 56 - spadek. Biorąc pod uwagę ludność wiejską to maksymalne wartości przyrostu rzeczywistego są dużo większe (np. w powiecie polickim wzrost liczby ludności o $52 \%$, piaseczyńskim - o $43 \%$, poznańskim $37 \%$, czy legionowskim - 33\%). Największy zaś spadek zaludnienia w badanym okresie zanotowały powiaty: lubański (o 19\%), krasnostawski (o 18\%), grójecki (14\%), wysokomazowiecki (13\%), białogardzki (12\%), hajnowski i sokólski (11\%). W układzie przestrzennym największym ubytkiem rzeczywistym ludności charakteryzowały się powiaty położone peryferyjnie w stosunku do większych ośrodków miejskich. 


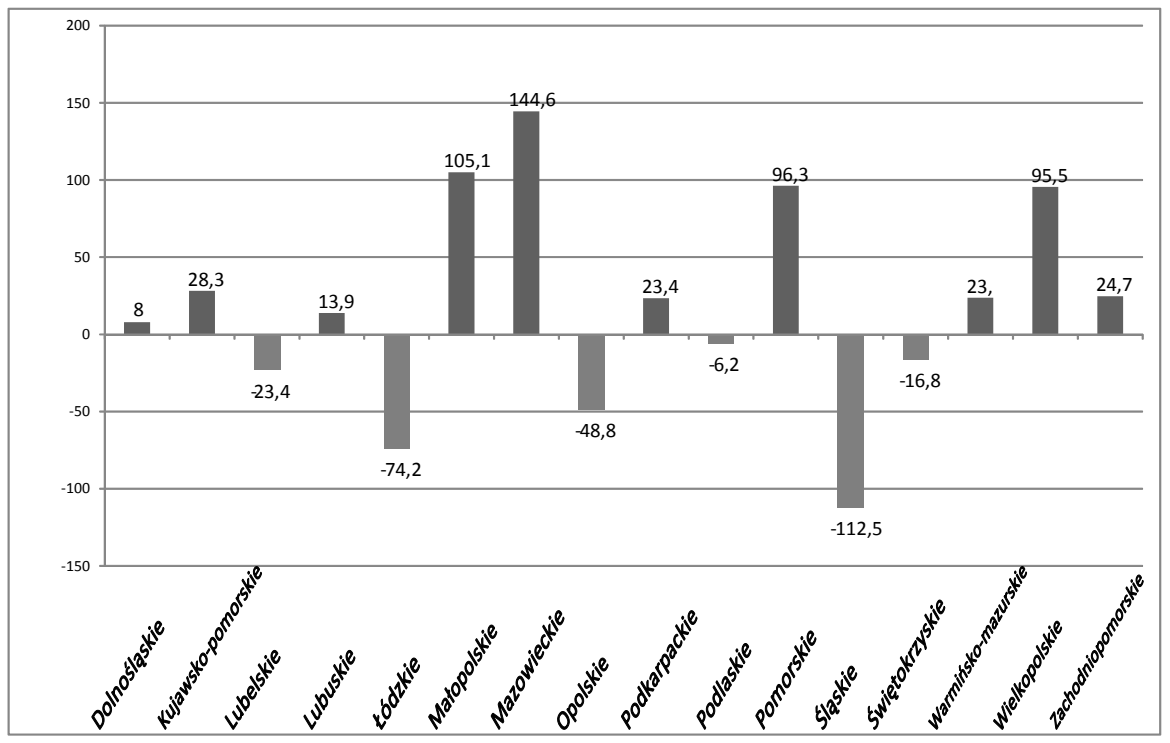

Ryc. 1. Przyrosty i ubytki liczby ludności ogółem wg województw w latach 2002-2011 (w tys. osób)

Źródło: opracowanie własne na podstawie danych GUS

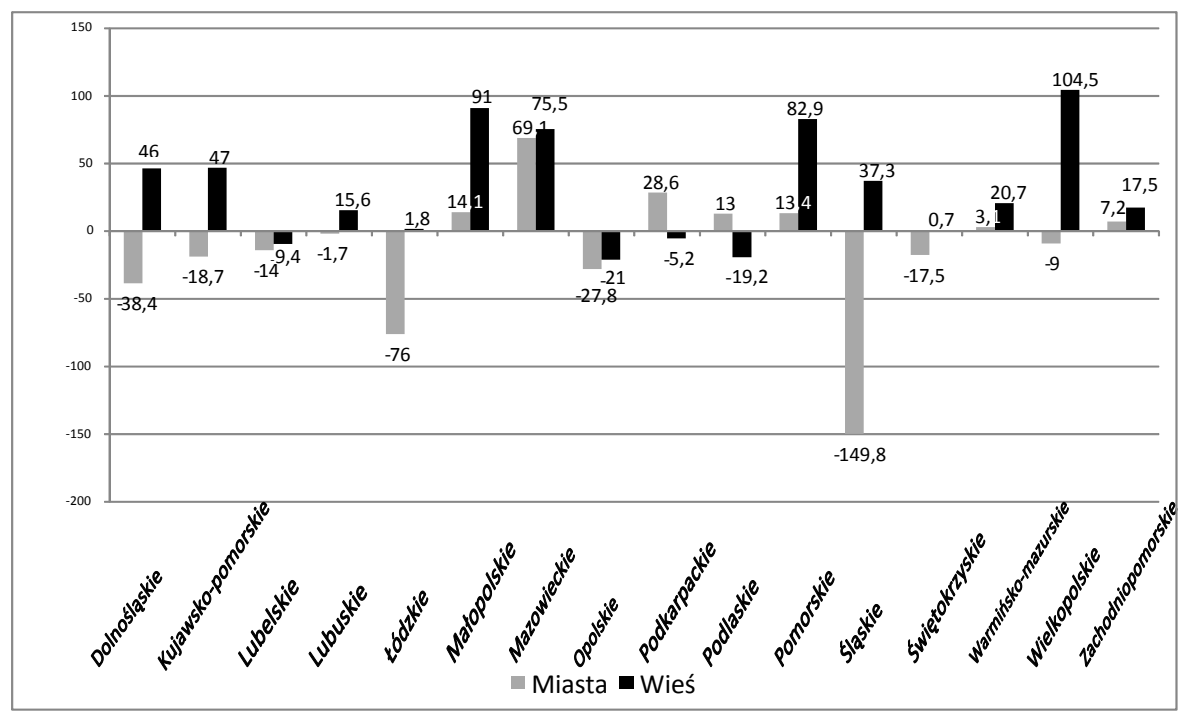

Ryc. 2. Przyrosty i ubytki liczby ludności miast i wsi wg województw w latach 2002-2011 (w tys. osób)

Źródło: opracowanie własne na podstawie danych GUS 

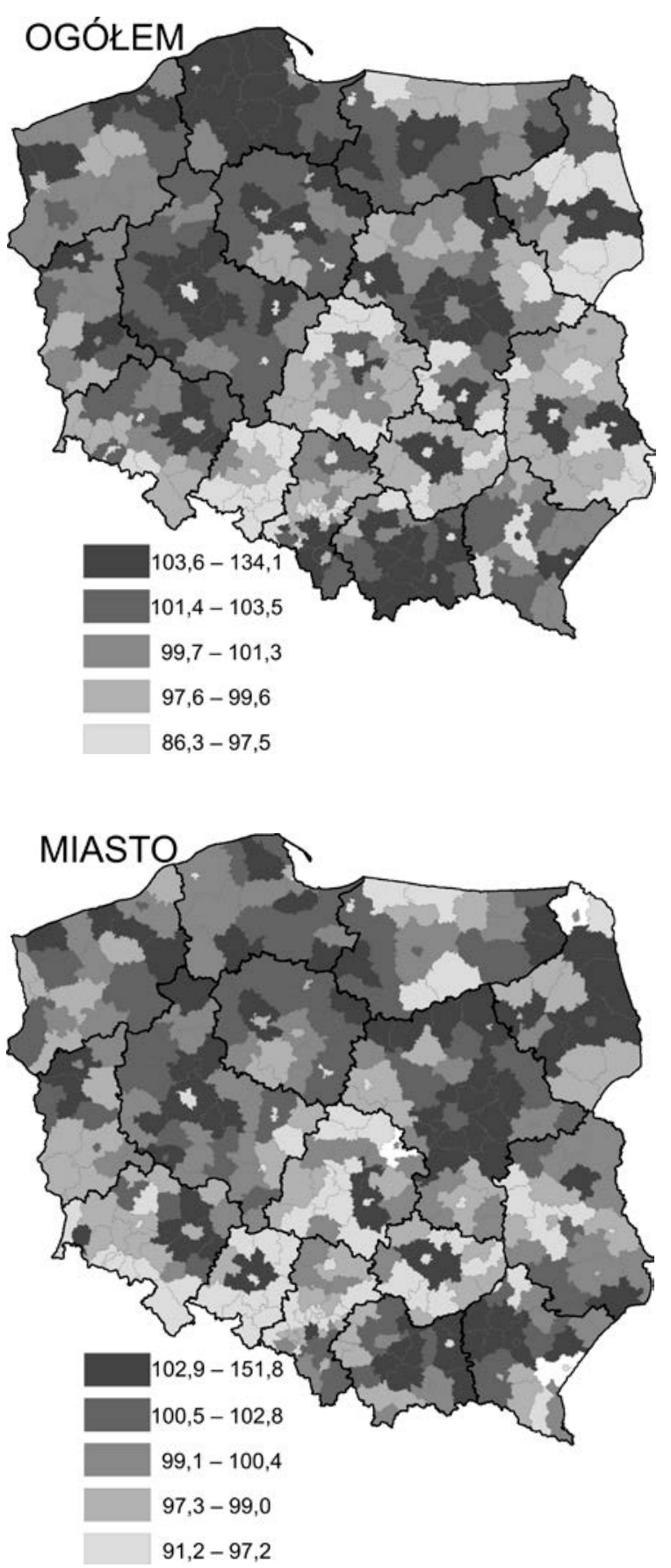


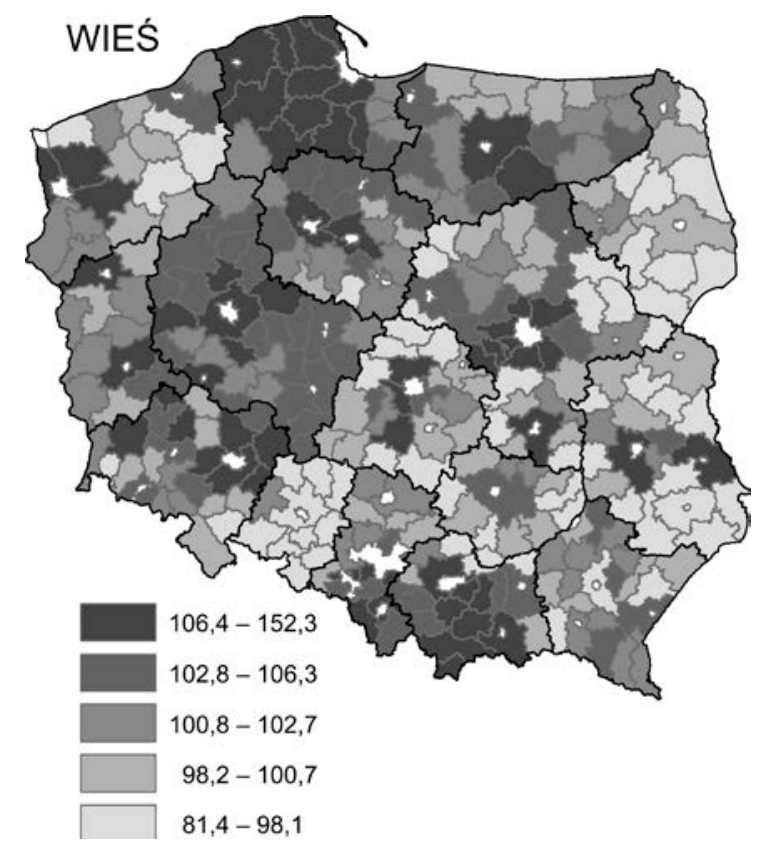

Ryc. 3. Dynamika zaludnienia w powiatach (ogółem, miasto, wieś) W okresie 2002-2011 (2002 = 100)

Źródło: opracowanie własne na podstawie danych GUS

\subsection{PRZYROST NATURALNY I RUCH WĘDRÓWKOWY LUDNOŚCI}

Jak powszechnie wiadomo, na przyrost rzeczywisty ludności składa się przyrost naturalny i saldo migracji. W zakresie przyrostu naturalnego, w $2011 \mathrm{r}$. najwyższe wartości współczynników zanotowano w Polsce północno-zachodniej (np. w powiecie kartuskim - 8\% i wejherowskim - 7\%o) oraz południowej (powiat limanowski i nowosądecki - 6\%o). Ogólnie w 2002 r. 215 powiatów charakteryzowało się dodatnim współczynnikiem przyrostu naturalnego, a w 2011 r. - 209 powiatów, zaś ich rozkład przestrzenny nie uległ zasadniczej zmianie (ryc. 4). Największym ubytkiem naturalnym w obu badanych przekrojach czasu charakteryzowały się powiaty: hajnowski i kazimierski oraz m. Łódź i Sopot (pomiędzy -6 a $-7 \%$ ). Powiaty o wysokim poziomie przyrostu naturalnego obejmowały pas ciągnący się od aglomeracji poznańskiej poprzez bydgosko-toruńską po Trójmiasto, a ponadto wystąpiły w województwie małopolskim i podkarpackim. Z kolei ubytkek naturalny ludności wystąpił w powiatach położonych w województwach: podlaskim, lubelskim, łódzkim, opolskim i świętokrzyskim, a także w północnej i środkowej części województwa śląskiego oraz w regionie Sudetów. W ujęciu dynamicznym w okresie 2002-2011 nieco więcej jednostek (205 na 379) zanotowało spadek poziomu przyrostu 
naturalnego ludności. Z kolei, największy wzrost wartości przyrostu naturalnego wystąpił $\mathrm{w}$ powiatach aglomeracji stołecznej i poznańskiej (np. w powiecie piaseczyńskim o 5 punktów promilowych, a w powiecie poznańskim, pruszkowskim i m. Warszawa o 4 punkty promilowe).
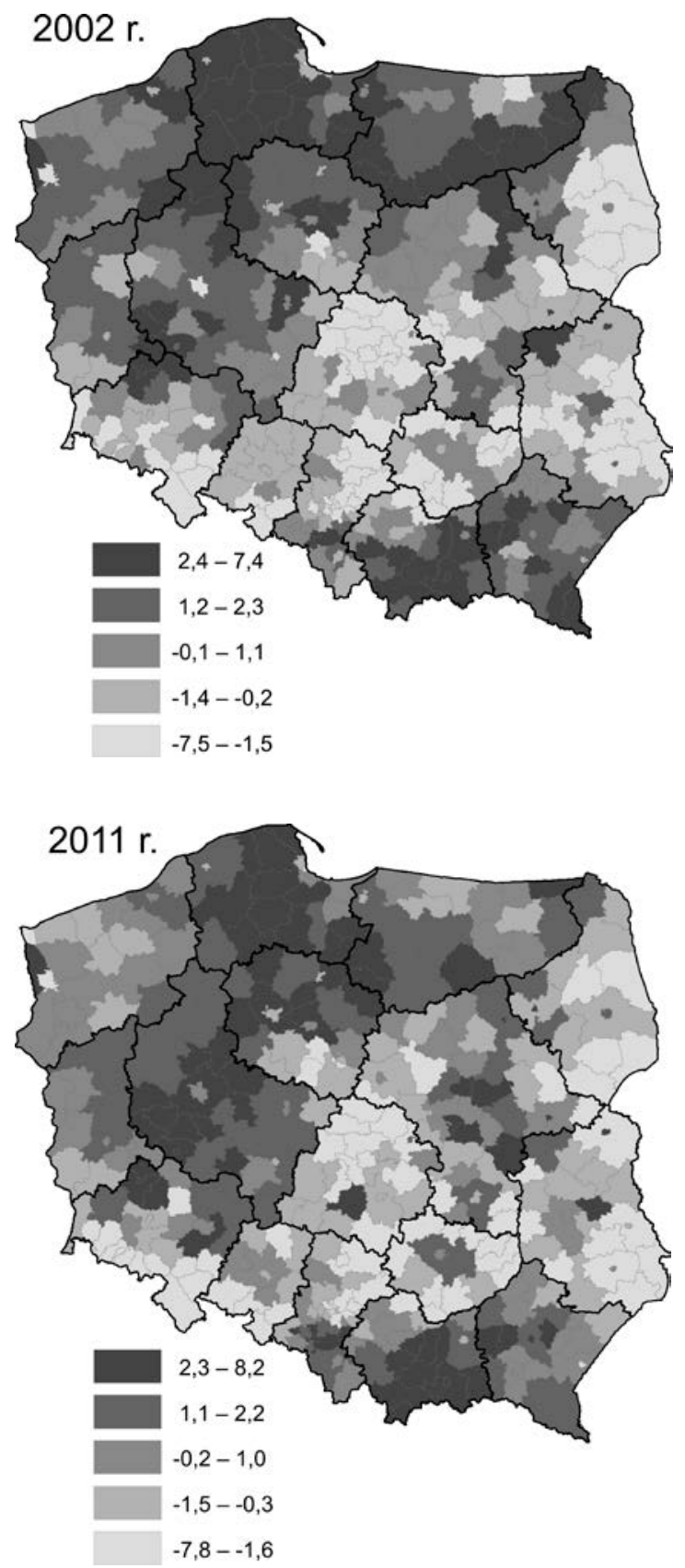


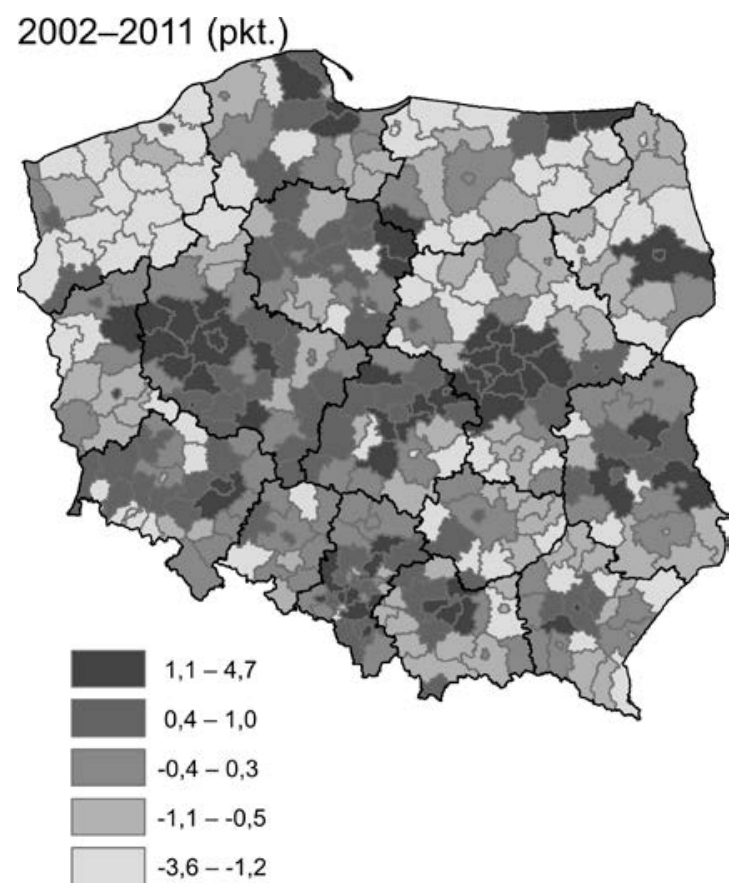

Ryc. 4. Przyrost naturalny na 1000 ludności według powiatów w latach 2002-2011 r.

Źródło: opracowanie własne na podstawie danych GUS

W przypadku salda migracji, w 2002 r. 110 powiatów charakteryzowało się dodatnim bilansem ruchu wędrówkowego ludności, a najwyższe wartości notowano w sąsiedztwie dużych miast (np. w powiatach: piaseczyńskim - 26\%o, poznańskim - 16\%o, warszawskim zachodnim - 14\%o). Największy ubytek migracyjny wystąpił głównie $\mathrm{w}$ powiatach położonych peryferyjnie lub na terenach poprzemysłowych (np. powiat krośnieński w województwie lubuskim 8\%, hrubieszowskim i m. Jastrzębie-Zdrój - 7\%o oraz w powiecie sokólskim, łosickim oraz hajnowskim - 6\%o). W 2011 r. dodatnie saldo migracji zanotowano już tylko w 99 powiatach, co stanowiło około 1/4 wszystkich badanych jednostek. Największe wartości zanotowano ponownie $\mathrm{w}$ powiatach otaczających duże miasta (np. wrocławskim - 22\%o, gdańskim - 19\%o, poznańskim $17 \%$ oraz piaseczyńskim $-15 \%$ ). Najniższy poziom migracji netto zanotowano w powiatach grodzkich (np. Jastrzębiu-Zdroju i Świętochłowicach - ubytek naturalny po $7 \%$, Ostrołęka i Konin po 6\%o) oraz peryferyjnych (powiat braniewski - 9\% oraz bartoszycki, hrubieszowski i bieszczadzki - 6\%). W okresie 2002-2011 największy spadek poziomu salda migracji zaobserwowano $\mathrm{w}$ powiatach grodzkich oraz powiatach położonych $\mathrm{w}$ województwie opolskim (ryc. 5). 

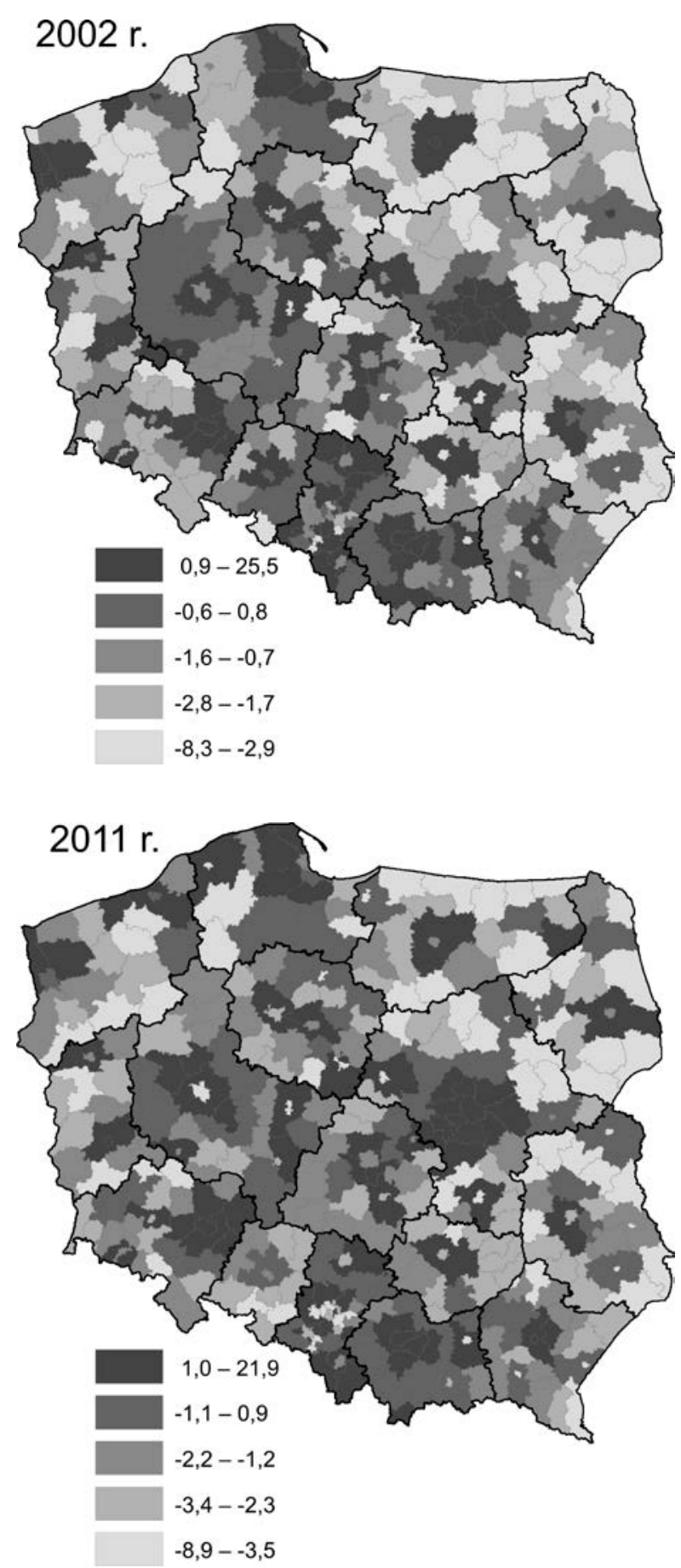


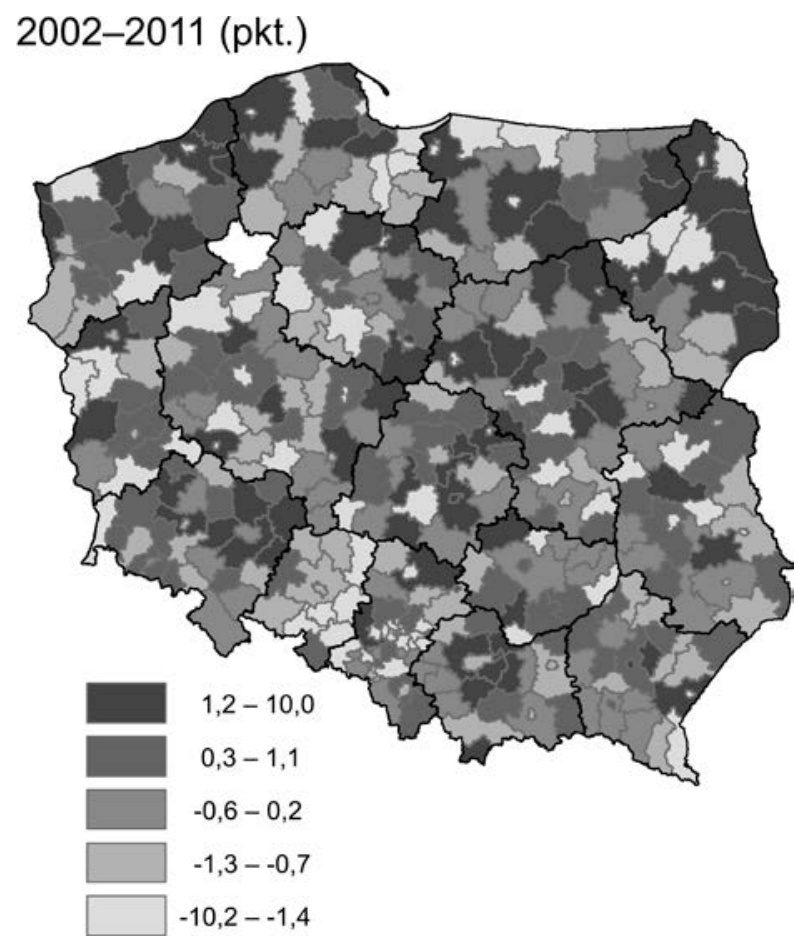

Ryc. 5. Saldo migracji na 1000 ludności według powiatów w latach 2002-2011 r.

Źródło: opracowanie własne na podstawie danych GUS

Jeśli chodzi o migracje zagraniczne ludności, to według szacunków GUS (2013) w 2011 r. za granicą przebywało czasowo (powyżej 3 miesięcy) 2017501 Polaków, z czego około ²/3 pochodziło z miast. Najwięcej emigrantów pochodziło $\mathrm{z}$ województwa śląskiego (230,9 tys.), następnie $\mathrm{z}$ województwa małopolskiego (187,5 tys.) oraz dolnośląskiego (181,5 tys.). W ujęciu procentowym jednakże (GUS 2013), największy udział ludności przebywającej za granicą zanotowano w województwie opolskim (10,6\% ogółu ludności), podlaskim $(9,1 \%)$ oraz podkarpackim $(8,4 \%)$. Najmniej natomiast wyjechało osób z województwa mazowieckiego $(2,8 \%)$, łódzkiego $(2,9 \%)$ oraz wielkopolskiego (3,1\%). Najwięcej ludności przebywało w Wielkiej Brytanii (611,7 tys.), następnie w Niemczech (435,2 tys.) oraz Stanach Zjednoczonych (218,8 tys.). Z większości województw, najwięcej osób ubyło do Wielkiej Brytanii, za wyjątkiem województwa opolskiego i śląskiego, skąd emigranci koncentrowali się głównie w Niemczech oraz województwa podlaskiego, gdzie najwięcej ich wyjechało do USA. 
Aby stwierdzić, jakie są relacje między głównymi składowymi przyrostu rzeczywistego ludności, wykonano typologię Webba dla powiatów (ryc. 6; tab. 1). Do analizy przyjęto sumę wartości przyrostu naturalnego i salda migracji za okres od 2002 do 2011 r. Typem A, o dodatnim współczynniku przyrostu naturalnego, rekompensującym ubytek migracyjny, charakteryzowało się około $16 \%$ powiatów, większość $\mathrm{z}$ nich położonych było w województwie wielkopolskim, pomorskim oraz kujawsko-pomorskim, w peryferyjnej strefie aglomeracji poznańskiej, trójmiejskiej i bydgosko-toruńskiej. Jednostki typu B (7\% ogółu), w których dodatni przyrost naturalny był większy od dodatniego salda migracji, rozmieszczone były przede wszystkim w południowej części województwa małopolskiego oraz wokół aglomeracji poznańskiej (bliżej rdzenia niż powiaty typu A). Powiaty reprezentujące typ C, odpowiadały obszarom znajdującym się w fazie suburbanizacji, położonym wokół większych miast (np. powiat krakowski, wrocławski, warszawski zachodni, rzeszowski, poznański, gdański). W typie czwartym, charakteryzującym się ubytkiem naturalnym ludności, ale rekompensowanym przez saldo migracji, znalazły się powiaty grodzkie (Warszawa, Kraków), powiaty położone w dalszej strefie aglomeracji stołecznej (np. sochaczewski, żyrardowski) oraz w strefie podmiejskiej miast średnich (np. powiat płocki, siedlecki, częstochowski). Generalnie, typ ten był słabo reprezentowany (4\% ogółu jednostek). Typ E był najsłabiej reprezentowany (tylko 3\% wszystkich powiatów) i obejmował jednostki, w których dodatnie saldo migracji nie równoważyło ubytku naturalnego. Zanotowano tu powiat $\mathrm{m}$. Wrocław oraz niektóre jednostki położone w otoczeniu średnich lub dużych miast na terenie województw o słabej dynamice demograficznej (np. powiat opolski, zamojski, skierniewicki, pabianicki, łomżyński). Kolejny, typ F, charakteryzujący się zarówno ubytkiem naturalnym (większym), jak i wędrówkowym wystąpił głównie na obszarach położonych w oddaleniu od głównych ośrodków (np. w Kotlinie Kłodzkiej, na Podlasiu czy na Lubelszczyźnie). Ponadto, zaklasyfikowano tu takie powiaty grodzkie jak Chorzów, Jelenia Góra, Łódź, Sopot, Szczecin, Świnoujście. Typy G i H były najliczniej reprezentowane (po 25\% ogółu powiatów), z tymże w typie G ubytek migracyjny przewyższał ubytek naturalny, natomiast w typie $\mathrm{H}$ współczynnik przyrostu naturalnego miał znak dodatni, ale nie równoważył ubytku migracyjnego, więc powiaty te charakteryzowały się ubytkiem rzeczywistym. Powiaty typu G obejmowały obszary peryferyjne i zlokalizowane były głównie na terenie województw: podlaskiego, lubelskiego i opolskiego. Ponadto w skład tej grupy weszły także powiaty grodzkie rozmieszczone w obrębie GOP (m.in. Bytom, Gliwice, Katowice, Zabrze). Jednostki typu $\mathrm{H}$ rozmieszczone były na terytorium Polski północnej i północno-zachodniej (województwa: warmińsko-mazurskie, zachodniopomorskie i lubuskie) oraz w województwie podkarpackim. Przedstawiona typologia przyrostu rzeczywistego ludności ukazuje wyraźną polaryzację 
procesów demograficznych kraju z wzrostem zaludnienia w obszarach metropolitalnych i depopulacją $\mathrm{w}$ obszarach położonych peryferyjnie $\mathrm{w}$ stosunku do większych aglomeracji. Dominującym czynnikiem ubytku rzeczywistego ludności jest ujemne saldo migracji (50\% ogółu jednostek - typ G i H), natomiast ubytek naturalny jest główną przyczyną spadku ludności w $12 \%$ ogółu powiatów (typy E i F).

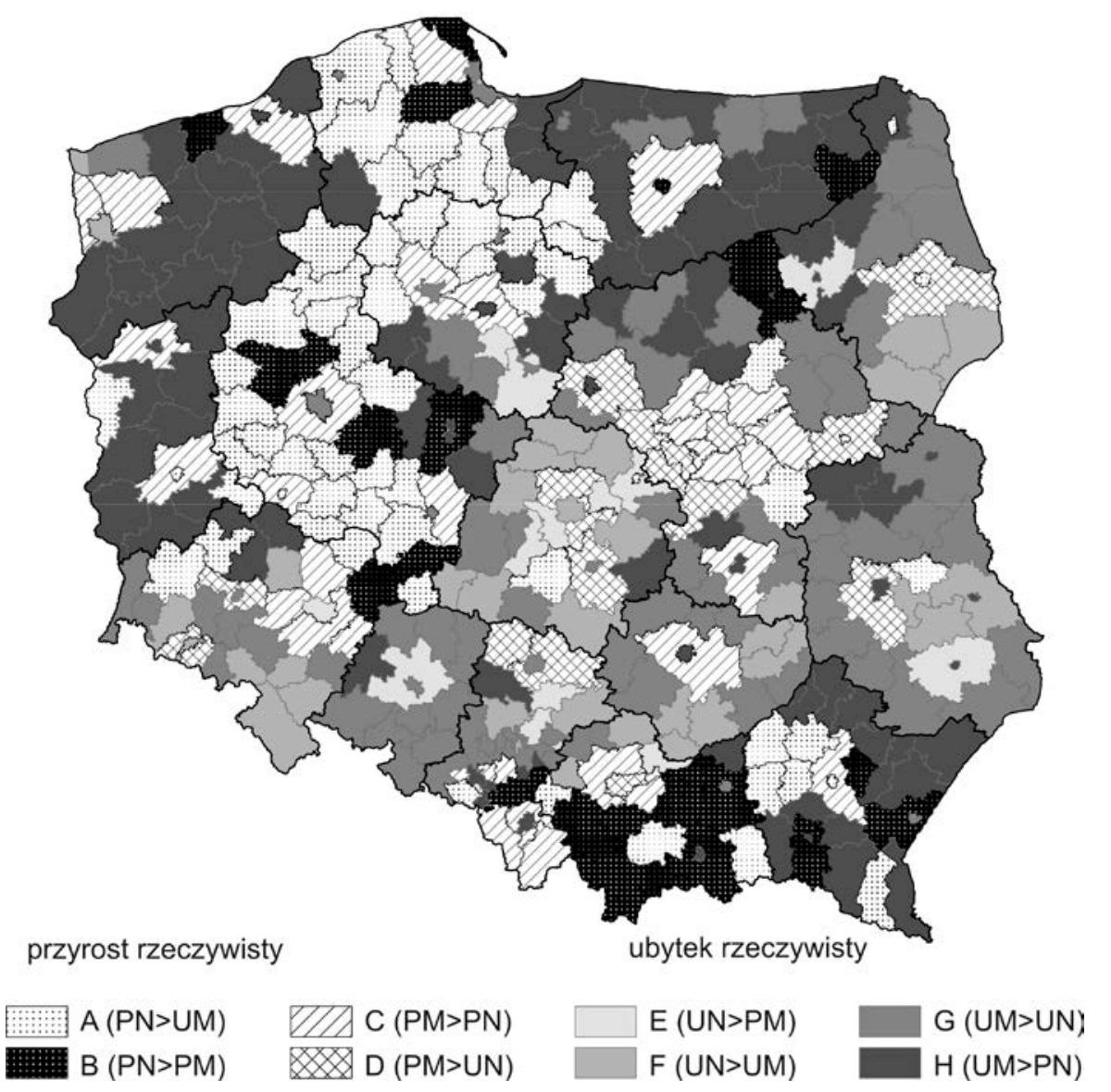

Ryc. 6. Typologia Webba w latach 2002-2011

(PN - przyrost naturalny, UN - ubytek naturalny, PM - przyrost migracyjny,

UM - ubytek migracyjny)

Źródło: opracowanie własne na podstawie danych GUS 
Tabela 1

Liczebność i udział procentowy powiatów według typów Webba

\begin{tabular}{|l|c|c|c|}
\hline \multirow{2}{*}{ Typ } & \multicolumn{2}{|c|}{ Powiaty ogółem } & \multirow{2}{*}{$\begin{array}{c}\text { w tym: } \\
\text { powiaty grodzkie }\end{array}$} \\
\cline { 2 - 3 } A & liczba & $\%$ & 7 \\
\hline B & 62 & 16,4 & 1 \\
\hline C & 27 & 7,1 & 0 \\
\hline D & 35 & 9,2 & 2 \\
\hline E & 17 & 4,5 & 1 \\
\hline F & 13 & 3,4 & 6 \\
\hline G & 36 & 9,5 & 26 \\
\hline H & 93 & 24,5 & 22 \\
\hline Razem & 379 & 25,3 & 65 \\
\hline
\end{tabular}

Źródło: opracowanie własne.

\subsection{ZMIANY W STRUKTURZE WIEKU LUDNOŚCI}

Konsekwencją zmian w ruchu naturalnym i wędrówkowym ludności są przemiany w strukturze wieku populacji, prowadzące najczęściej do starzenia się społeczeństwa. W okresie 2002-2011 liczba ludności przedprodukcyjnej w Polsce zmniejszyła się o 1648 tys. (z 23,2 do 18,7\% ogółu populacji), a liczba ludności $\mathrm{W}$ wieku poprodukcyjnym wzrosła o 763 tys. (z 15 do 16,9\%; ryc. 7 i 8). Wzrost nastąpił w grupie ludności produkcyjnej (z 61,8 do 64,4\%), lecz większość tego przyrostu dotyczyła ludności w wieku niemobilnym (o 994 tys.). W miastach spadek liczby ludności przedprodukcyjnej (o 998 tys.) był dużo większy niż na wsi (o 650 tys.) i w miastach (w przeciwieństwie do wsi) nastąpił także spadek liczby osób w wieku mobilnym (o 235 tys.). Wzrost liczby i udziału ludności w wieku produkcyjnym wynikał z przesuwania się w piramidzie wieku roczników wyżowych (zarówno z lat 50., jak i przełomu lat 70. i 80.). W perspektywie najbliższych lat jednak liczne roczniki wyżu powojennego będą odchodzić na emeryturę, co spowoduje znaczący spadek liczby i udziału ludności w wieku produkcyjnym.

W ujęciu przestrzennym różnice w udziałach ludności w wieku produkcyjnym pomiędzy powiatami ogółem sięgały w 2011 r. ośmiu punktów procentowych. Największe wartości wystąpiły w Polsce północnej i zachodniej oraz wśród ludności miast w powiatach uprzemysławianych intensywnie w latach 80. 
(np. łęczyński - 74\%, bełchatowski - 71\% oraz policki - 69\%). Najniższe wartości zanotowano wśród ludności wiejskiej w powiatach położonych w województwie podlaskim (powiat siemiatycki - 57\%, hajnowski - 56\% oraz bielski - 53\%; ryc. 9).

Nieco inny układ przestrzenny wystąpił w przypadku ludności w wieku produkcyjnym mobilnym (ryc. 10), z największymi udziałami w powiatach położonych w strefie podmiejskiej (np. gdański 44\%, poznański i wrocławski 43\%) oraz generalnie w województwie wielkopolskim, małopolskim i podkarpackim. Najniższe wartości zanotowano w powiecie hajnowskim (34\%) i bielskim (36\%) oraz w miastach: Jelenia Góra, Sopot i Łódź (po 37\%). Wśród ludności miast wysokie wartości ludności mobilnej były reprezentowane, oprócz województw wyżej wymienionych, także na pograniczu województwa warmińsko-mazurskiego i podlaskiego oraz częściowo w województwie lubelskim. Z kolei, niskie udziały ludności w wieku produkcyjnym mobilnym wystąpiły w Polsce środkowej oraz na tzw. ścianie wschodniej (w powiecie hajnowskim i bielskim, odpowiednio 31 i 32\%).

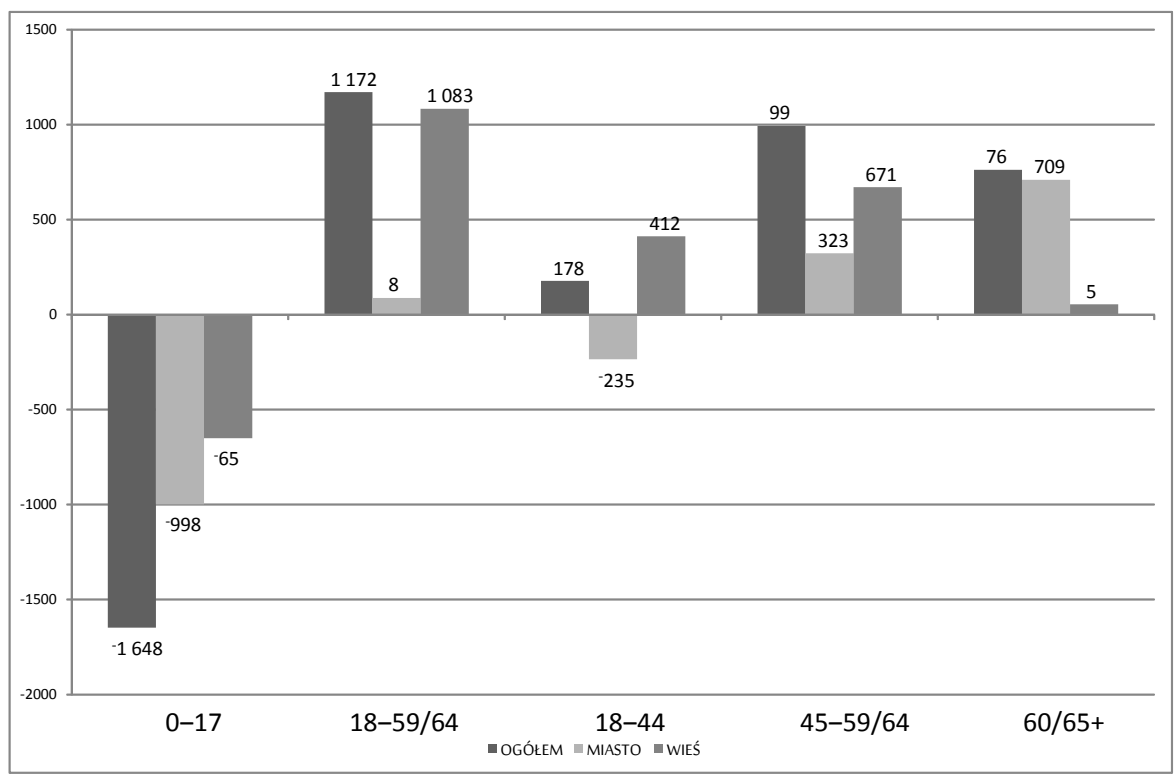

Ryc. 7. Zmiany liczby ludności w Polsce (ogółem) według ekonomicznych grup wieku w latach 2002-2011 r. (w tys. osób)

Źródło: opracowanie własne na podstawie danych GUS 

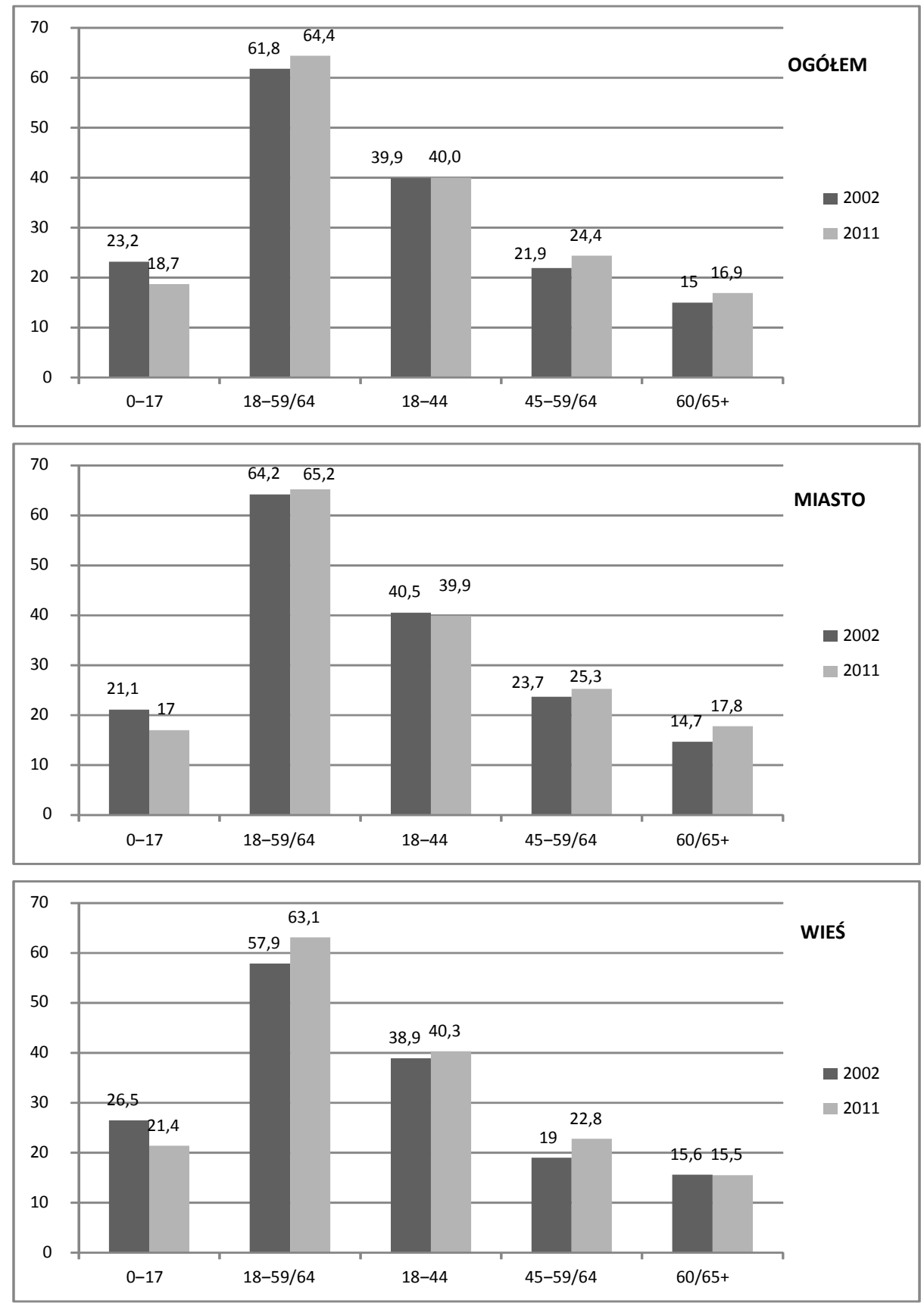

Ryc. 8. Udziały ludności według ekonomicznych grup wieku w Polsce (ogółem, miasto, wieś) w latach 2002-2011 r. (w \%) Źródło: opracowanie własne na podstawie danych GUS 

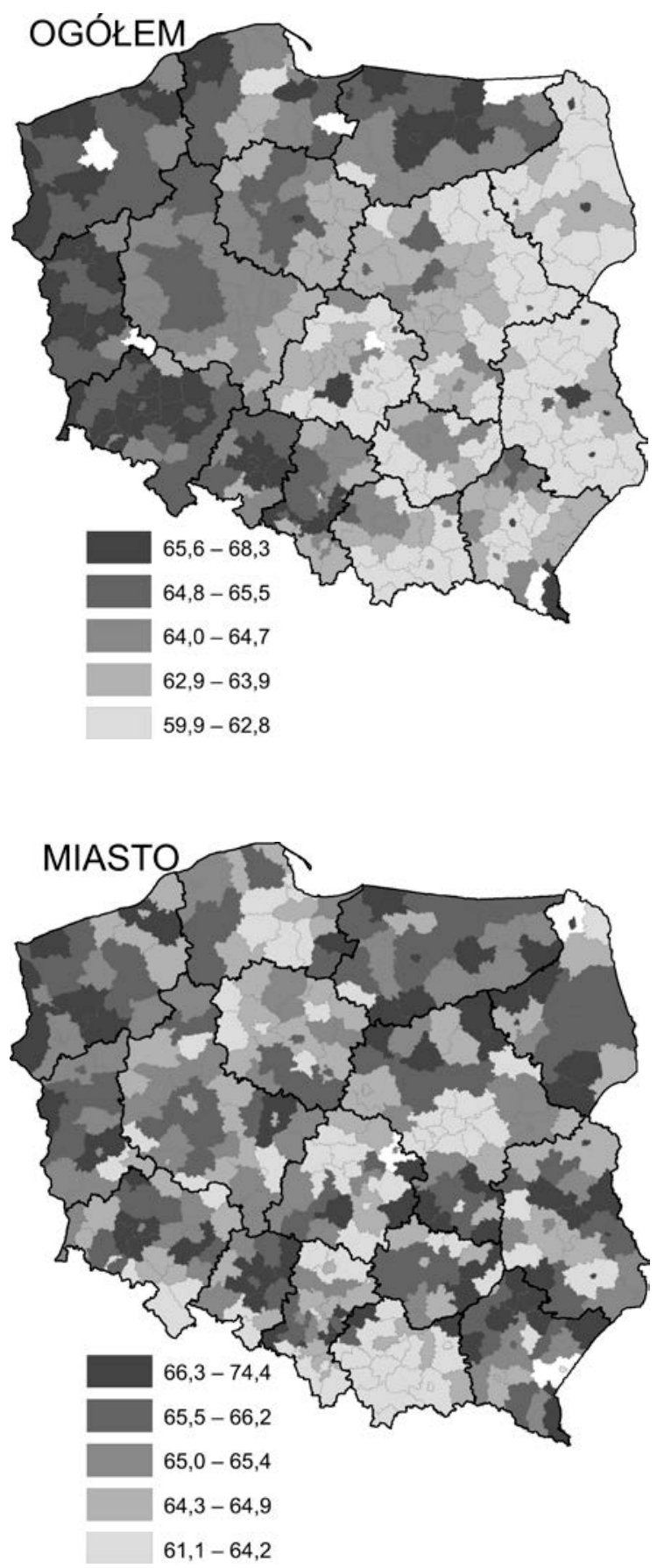


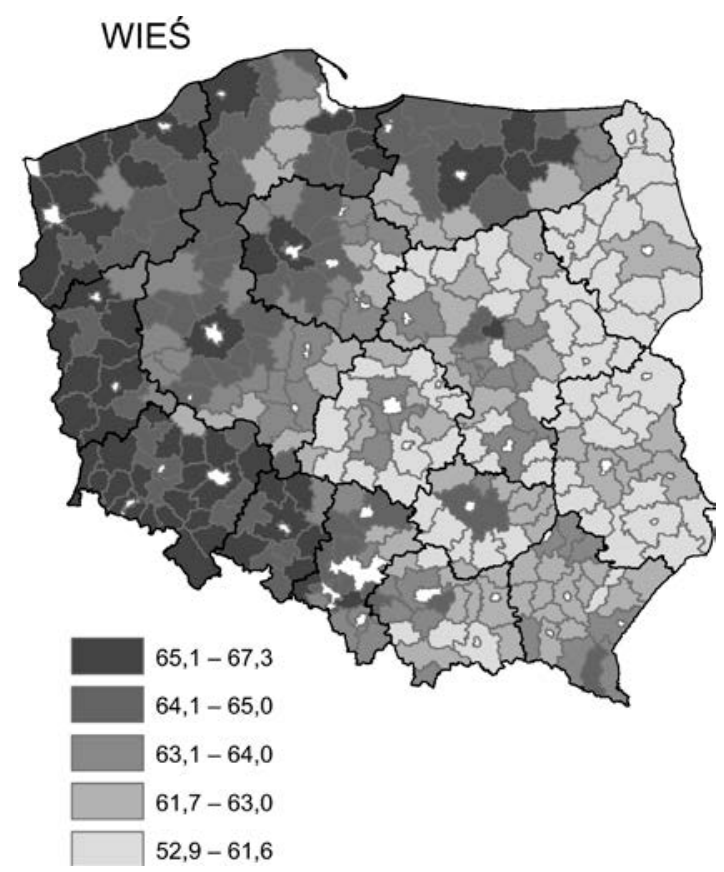

Ryc. 9. Ludność w wieku produkcyjnym w powiatach (ogółem, miasto, wieś) w 2011 r. (w \% ogółu ludności)

Źródło: opracowanie własne na podstawie danych GUS

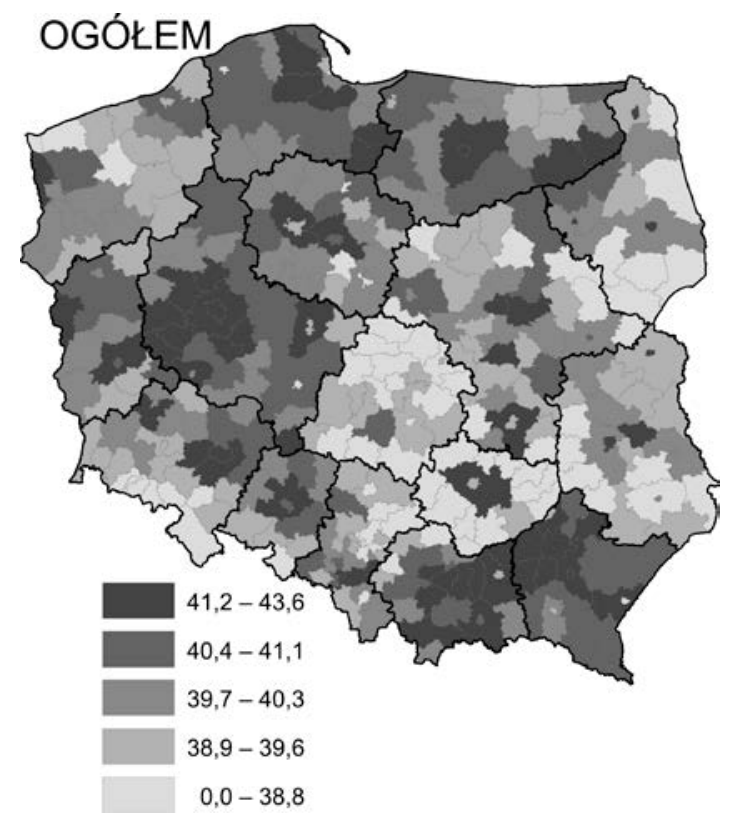



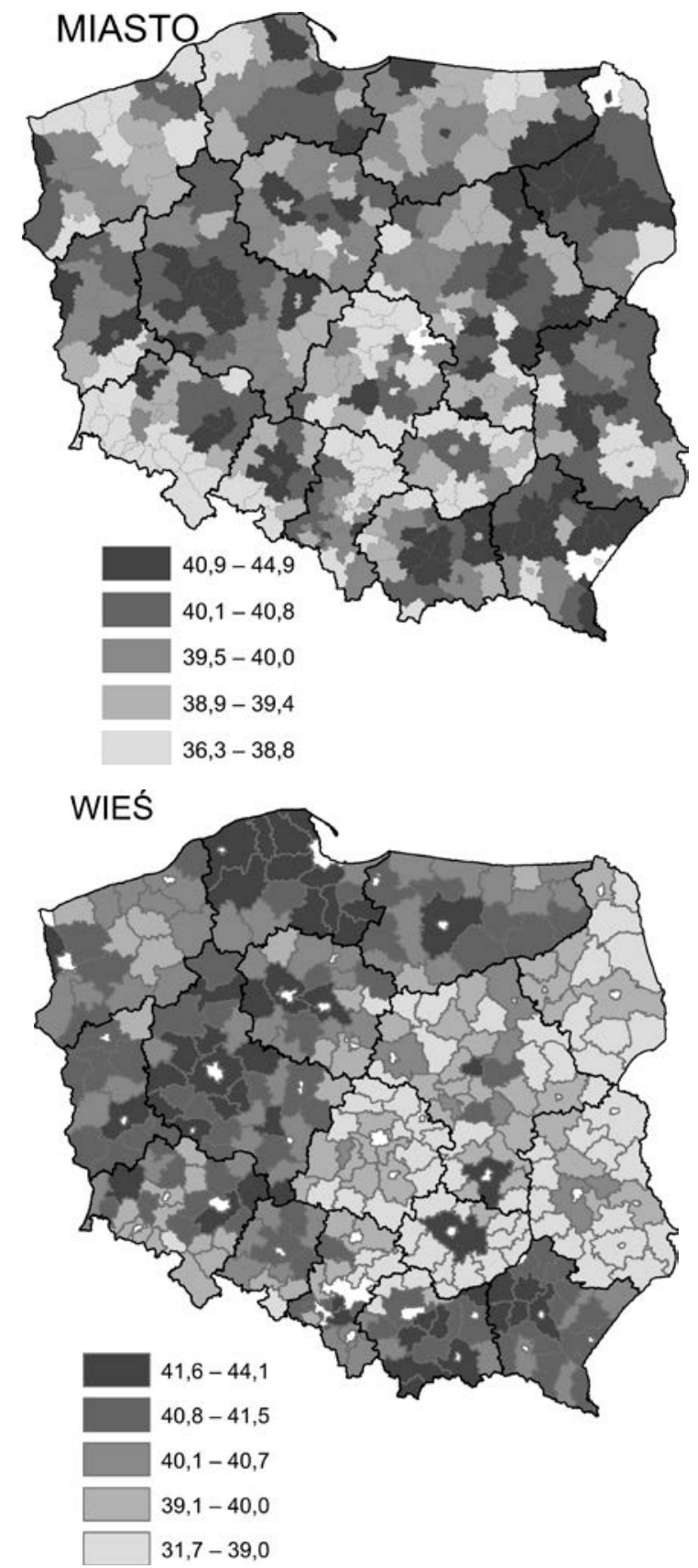

Ryc. 10. Ludność w wieku produkcyjnym mobilnym w powiatach (ogółem, miasto, wieś) w 2011 r. (w \% ogółu ludności) Źródło: opracowanie własne na podstawie danych GUS 
Powiaty o wysokich udziałach ludności w wieku produkcyjnym niemobilnym koncentrowały się w Polsce zachodniej i południowo-zachodniej (w województwach zachodniopomorskim, lubuskim i dolnośląskim, opolskim i śląskim; ryc. 11). Wartości ogółem kształtowały się od 20\% w powiecie limanowskim do 28\% w powiatach grodzkich Dąbrowa Górnicza i Sosnowiec. Wśród ludności miast największy odsetek ludności w starszym wieku produkcyjnym zaobserwowano m.in. w ośrodkach przemysłowych o wysokim napływie siły roboczej w latach 80 . (powiaty: łęczyński, bełchatowski, policki), a najniższe udziały wystąpiły w otoczeniu większych ośrodków (np. powiat gdański, piaseczyński i wołomiński). Na obszarach wiejskich najwyższe wartości wystąpiły w powiatach położonych w Sudetach (jeleniogórski, kłodzki, wałbrzyski), a najniższe w województwie małopolskim.

Przestrzenny rozkład odsetka ludności w wieku poprodukcyjnym (ryc. 12) odzwierciedlał podział demograficzny Polski na część młodszą północno-zachodnią oraz starszą - środkowo-wschodnią. Jedynie w przypadku ludności miast układ był nieco inny - $\mathrm{z}$ najwyższymi wartościami $\mathrm{w}$ województwie łódzkim, świętokrzyskim, śląskim i dolnośląskim. Najwyższe udziały zanotowano w powiatach grodzkich (Sopot - 26\%, Łódź - 23\%, Warszawa - 22\%) oraz powiatach położonych w województwie podlaskim (hajnowski - 25\% oraz bielski - 23\%). Wśród ludności wiejskiej, udziały ludności poprodukcyjnej w tych dwóch powiatach przekroczyły $30 \%$. Najniższe wartości dla ludności ogółem zanotowano w powiecie polickim (11\%) oraz kartuskim i wejherowskim (po 12\%).

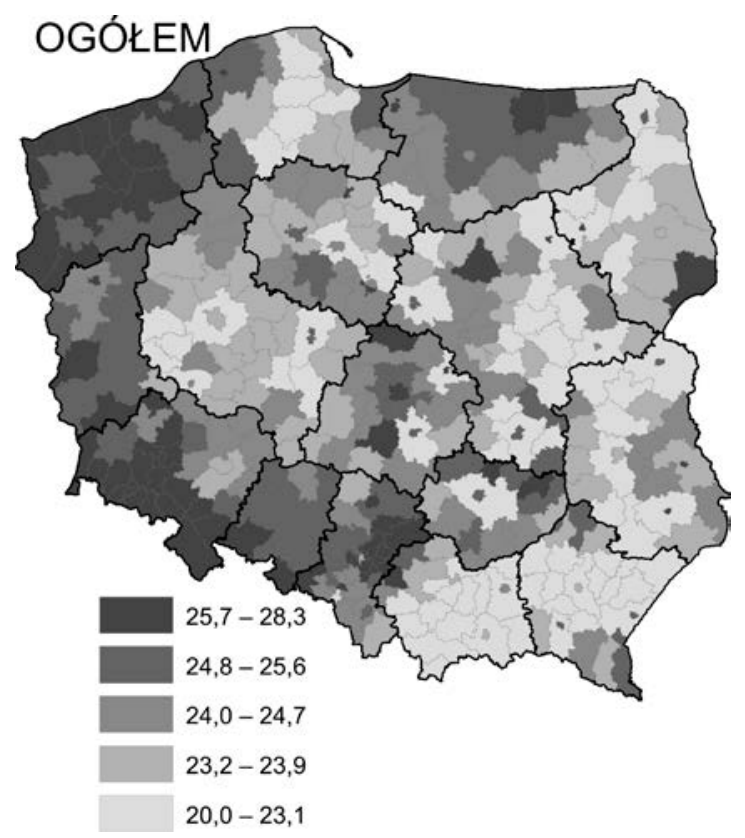



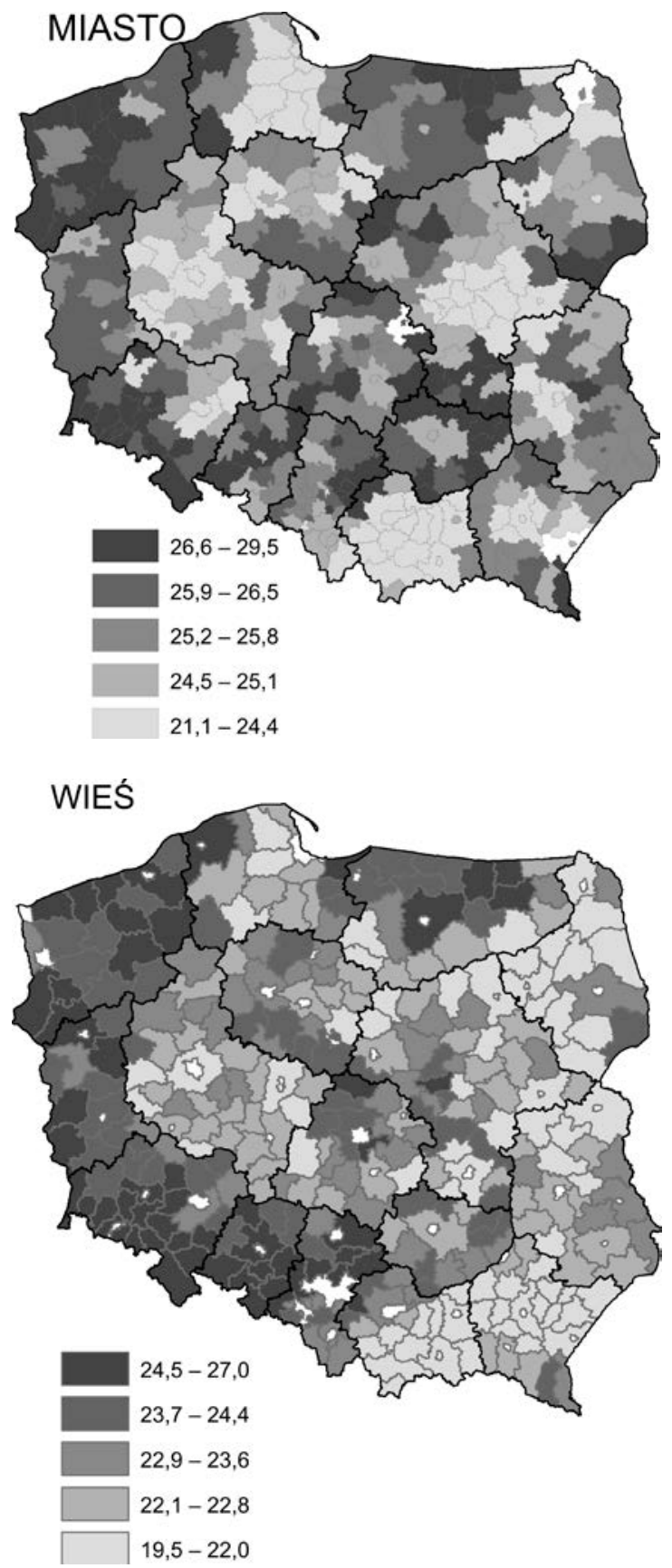

Ryc. 11. Ludność w wieku produkcyjnym niemobilnym w powiatach (ogółem, miasto, wieś) w 2011 r. (w \% ogółu ludności) Źródło: opracowanie własne na podstawie danych GUS 

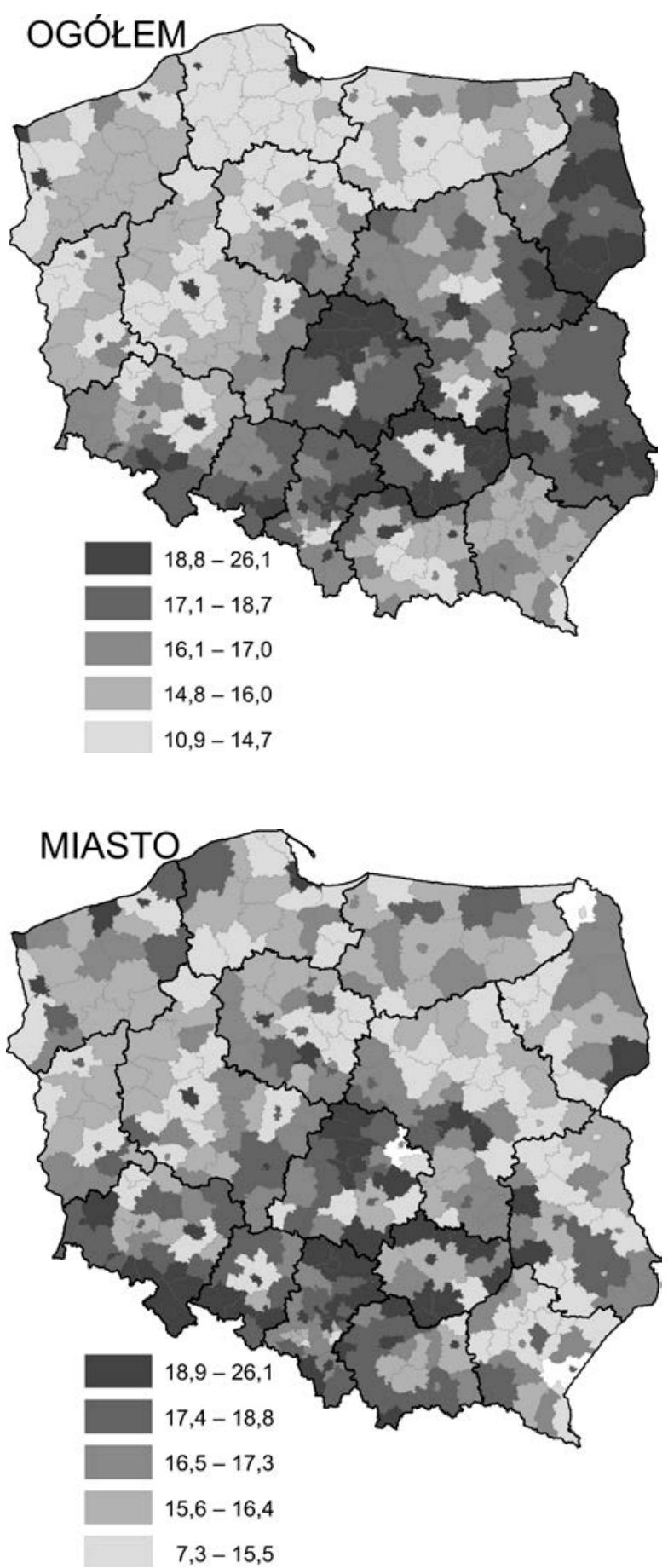


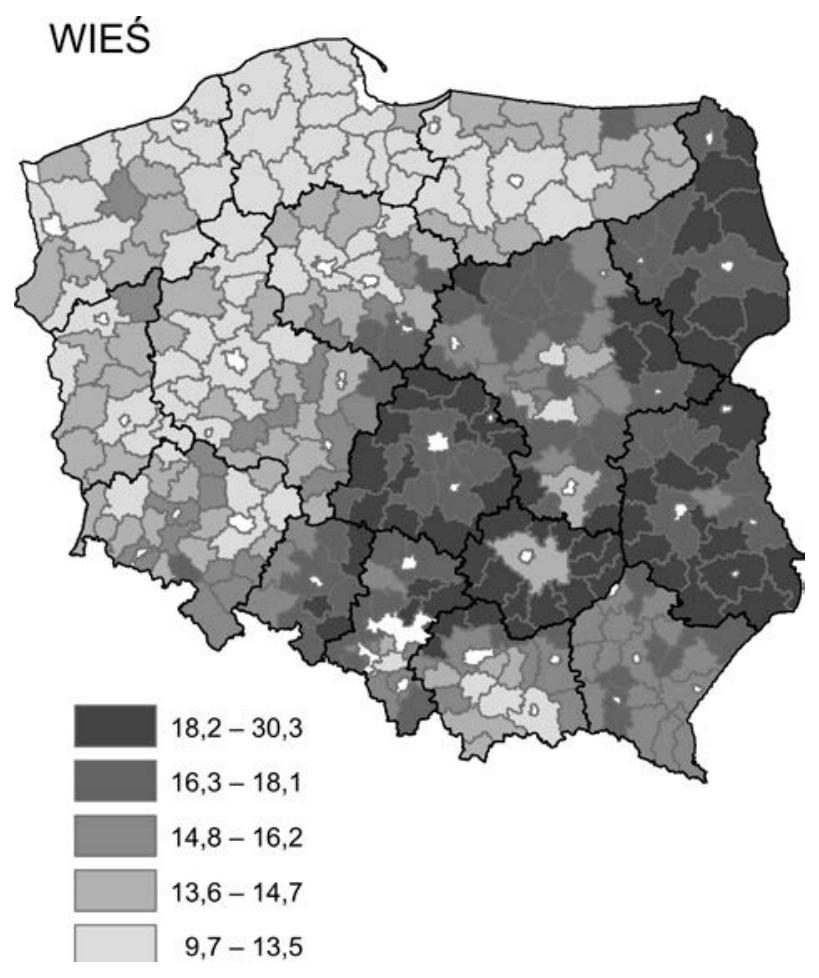

Ryc. 12. Ludność w wieku poprodukcyjnym w powiatach (ogółem, miasto, wieś) w 2011 r. (w \% ogółu ludności)

Źródło: opracowanie własne na podstawie danych GUS

Dynamiczny wskaźnik starzenia się ekonomicznego, obliczony na podstawie różnic w udziałach procentowych czterech ekonomicznych grup wieku (Kurek 2008), wskazuje na szybsze starzenie się populacji na terenach uznawanych do niedawna za relatywnie młodsze demograficznie, a więc w Polsce północnej i zachodniej (ryc. 13). Najsłabszą dynamiką charakteryzowały się powiaty położone $\mathrm{w}$ strefach podmiejskich, a największą powiaty grodzkie (średniej wielkości) oraz powiaty położone w województwie opolskim. 

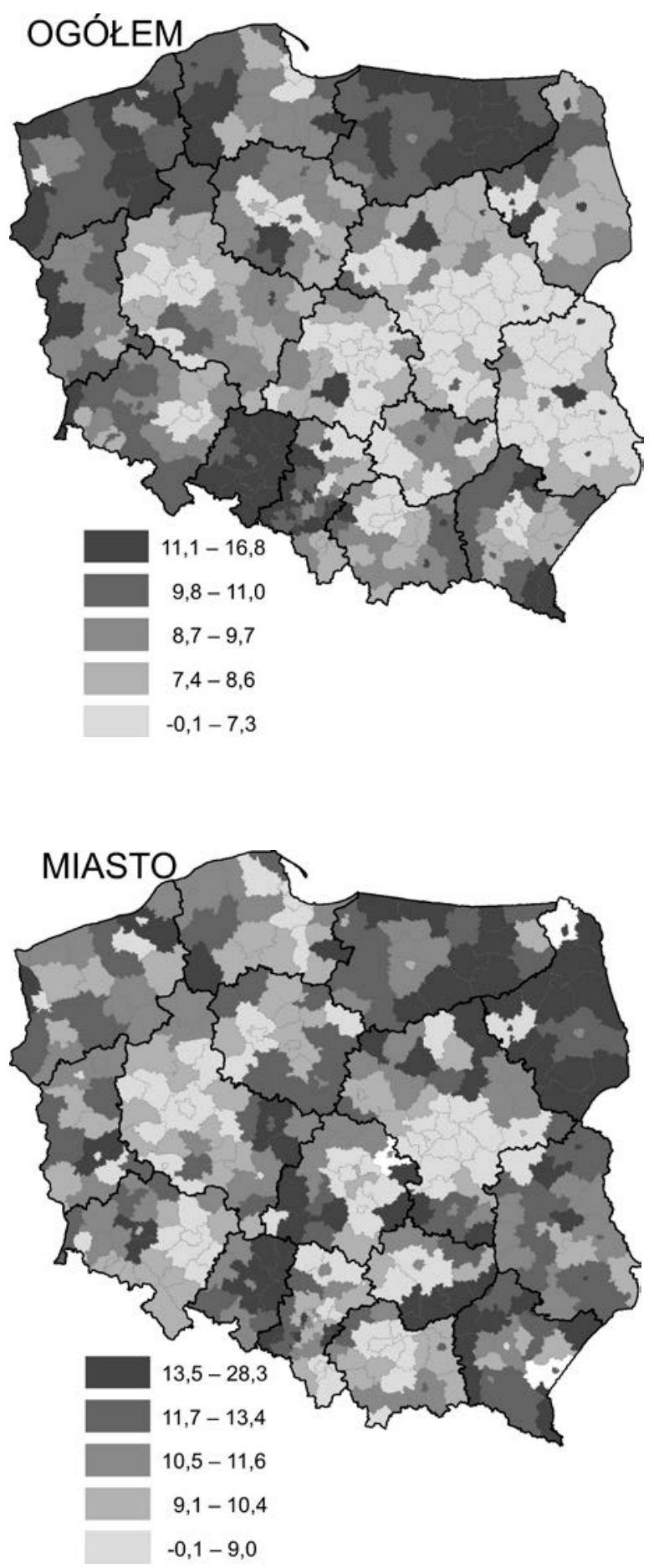


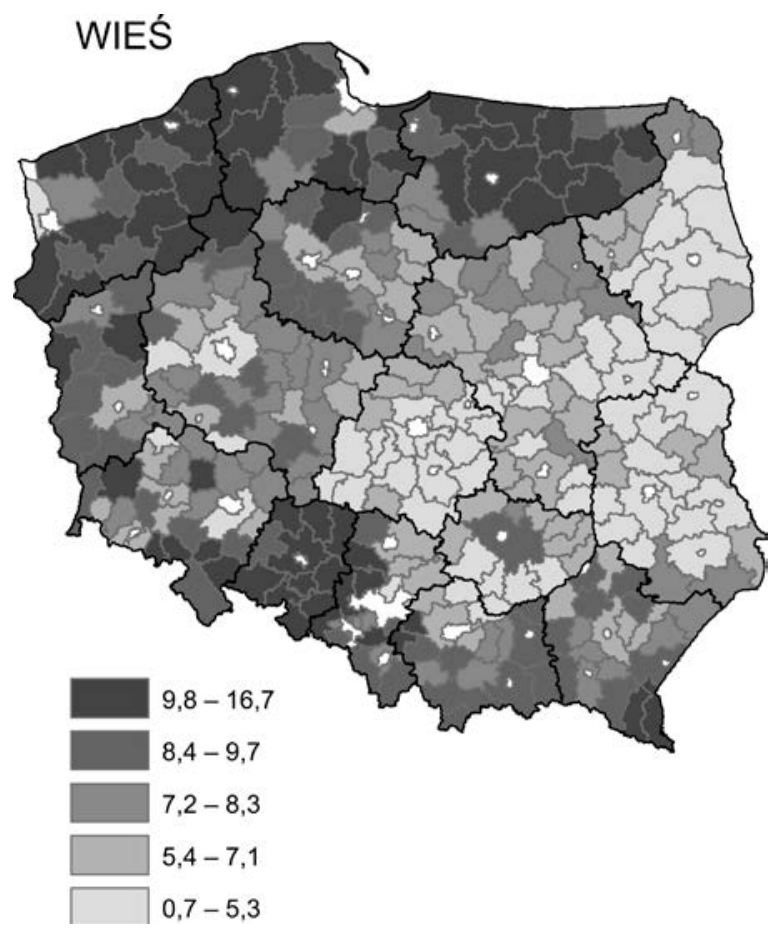

Ryc. 13. Wskaźnik starzenia się ekonomicznego w powiatach (ogółem, miasto, wieś)

w latach 2002-2011

Źródło: opracowanie własne na podstawie danych GUS

\subsection{TYPOLOGIA STRUKTURY WIEKU LUDNOŚCI}

W celu przedstawienia zróżnicowania przestrzennego struktury wieku ludności w ujęciu syntetycznym zastosowano metodę typografów (Długosz 1996). Wartości udziałów procentowych ekonomicznych grup wieku w poszczególnych powiatach w ogóle ludności odniesiono do średniej krajowej (tab. 2). Wśród badanych powiatów wystąpiło wszystkie 14 typów struktury wieku, jednak cztery spośród nich (typy B, E, G, I, J oraz L) były reprezentowane przez mniej niż 12 jednostek.

Najliczniej reprezentowany był typ A, charakteryzujący się względną młodością demograficzną na tle średniej dla Polski, z udziałami ludności przedprodukcyjnej i młodszej produkcyjnej powyżej wartości notowanych dla całego kraju. Obejmował on powiaty położone na terenie województwa podkarpackiego i małopolskiego oraz wielkopolskiego i pomorskiego (ryc. 14). Jednostki typu A zaobserwowano również $\mathrm{w}$ strefach podmiejskich dużych i średnich miast. 
Tabela 2

Rozkład typów struktury wieku ludności na podstawie odchyleń od średniej dla Polski

\begin{tabular}{|c|c|c|c|c|}
\hline Wiek/Typ & Przedprodukcyjny & $\begin{array}{c}\text { Produkcyjny } \\
\text { mobilny }\end{array}$ & $\begin{array}{c}\text { Produkcyjny } \\
\text { niemobilny }\end{array}$ & Poprodukcyjny \\
\hline A & + & + & - & - \\
\hline B & + & + & - & + \\
\hline C & + & + & - & - \\
\hline D & + & + & - & - \\
\hline E & - & - & - & + \\
\hline F & + & + & - & + \\
\hline G & - & - & + & - \\
\hline H & + & + & + & + \\
\hline I & - & - & + & + \\
\hline J & + & - & + & + \\
\hline K & - & - & + & + \\
\hline L & - & - & + & + \\
\hline M & - & + & + & + \\
\hline N & - & + & + & + \\
\hline
\end{tabular}

Źródło: opracowanie własne.

Typ C (o wysokich udziałach ludności przedprodukcyjnej oraz produkcyjnej mobilnej i niemobilnej) był reprezentowany przez powiaty położone głównie na obszarze województw: warmińsko-mazurskiego, zachodniopomorskiego oraz lubuskiego. Jednostki typu D koncentrowały się w większości w północnej części województwa mazowieckiego. Z kolei typ $\mathrm{F}$ o ponadprzeciętnych udziałach ludności przed- i poprodukcyjnej charakterystyczny był dla Polski środkowej i środkowo-wschodniej (województwa: łódzkie, lubelskie oraz wschodnia część mazowieckiego). Typ H o wysokich udziałach ludności przedprodukcyjnej oraz produkcyjnej niemobilnej zasadniczo rozmieszczony był na obszarze tych województw co typ C, tylko w ich bardziej peryferyjnej części (o niższych udziałach ludności w wieku mobilnym). Typ K, o wyższych od średnich udziałach ludności produkcyjnej niemobilnej, wystąpił w Polsce południowo-zachodniej (w województwie śląskim, opolskim i dolnośląskim). Wyższe od średniej dla Polski udziały ludności poprodukcyjnej, przy niższych pozostałych ekonomicznych grupach wieku (typ M) były notowane w województwach: lubelskim, podlaskim, łódzkim, ale także objęły powiat 
m. Warszawy. Najmniej korzystny typ struktury wieku ludności, o wyższych od średniej udziałach ludności produkcyjnej niemobilnej oraz poprodukcyjnej, objął 71 powiatów i rozmieszczony był głównie w Polsce środkowej oraz południowo-zachodniej (województwa łódzkie, świętokrzyskie, śląskie, opolskie i dolnośląskie). Przeważały w nim powiaty grodzkie (37 jednostek).

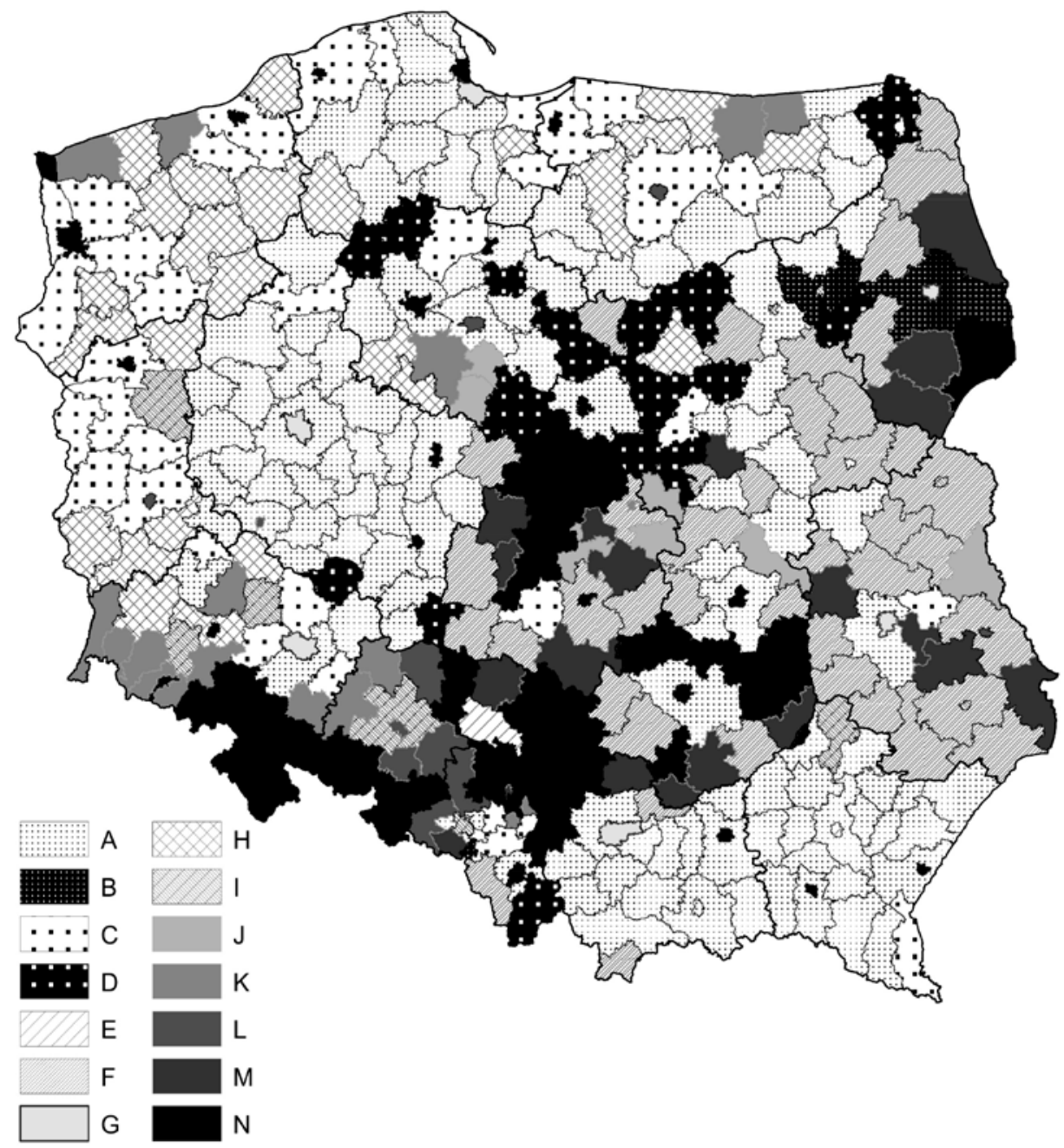

Ryc. 14. Typologia struktury wieku ludności na podstawie metody typografów według powiatów w 2011 r.

Źródło: opracowanie własne na podstawie danych GUS 
W perspektywie najbliższych dekad, przebiegające procesy demograficzne będą prowadzić do jeszcze większej polaryzacji przestrzennej pomiędzy obszarami metropolitalnymi a peryferyjnymi. Według prognozy GUS do $2035 \mathrm{r}$. (GUS 2011), liczba ludności Polski ogółem ulegnie zmniejszeniu do 36,0 milionów (o 2,5 miliona osób). W ujęciu powiatów (ryc. 15) największy wzrost zaludnienia wystąpi $\mathrm{w}$ powiatach otaczających duże miasta (np. w powiecie bydgoskim, poznańskim i piaseczyńskim o 42\%), a największy spadek liczby ludności w powiecie ryckim, hajnowskim i hrubieszowskim (o ponad 30\%).

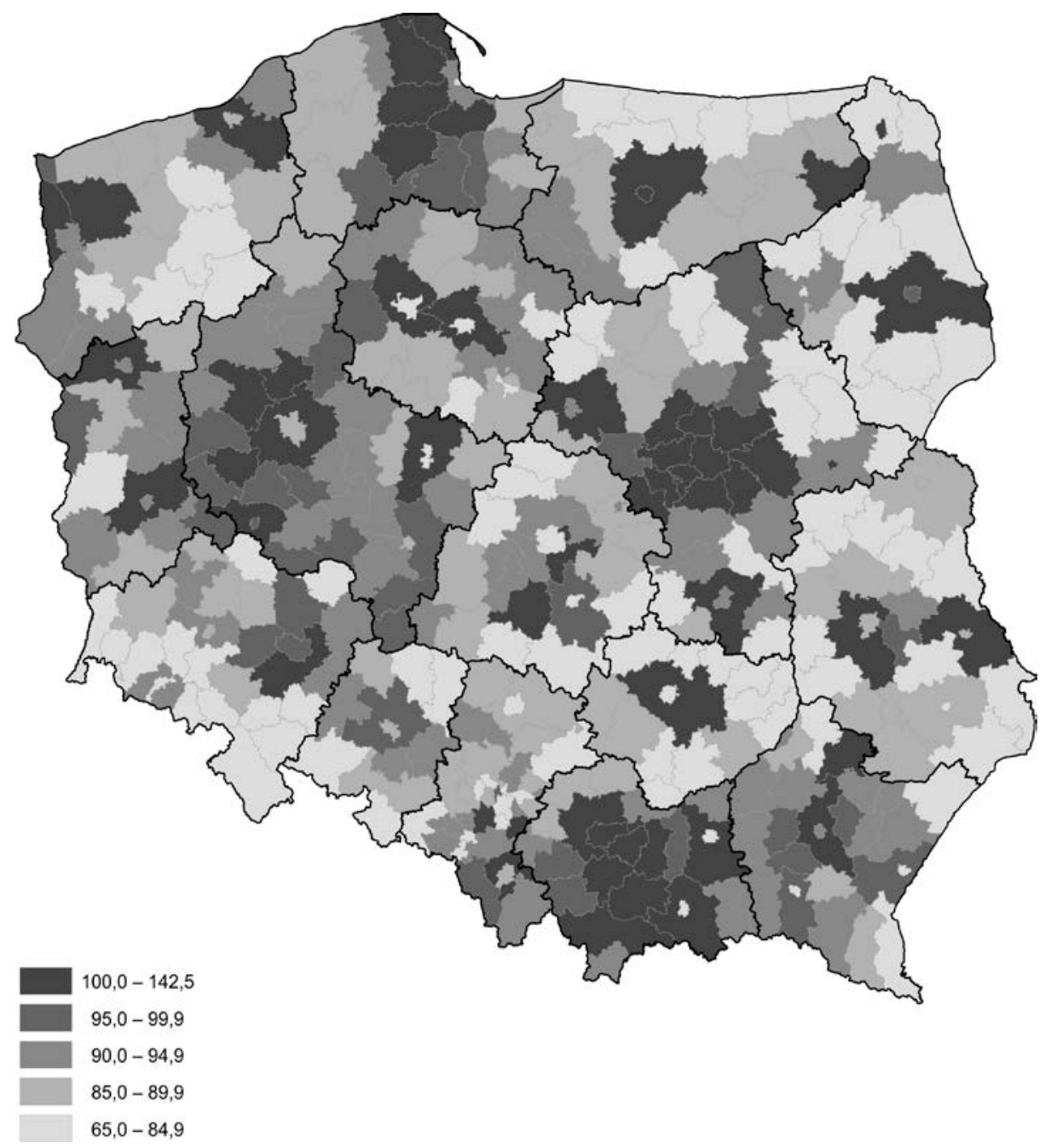

Ryc. 15. Prognoza dynamiki zaludnienia w latach 2011-2035 według GUS $(2011=100)$ Źródło: opracowanie własne na podstawie prognozy GUS (2011) 


\subsection{Podsumowanie}

Na początku XXI wieku w Polsce nastąpiły istotne zmiany w rozmieszczeniu ludności polegające na jej koncentracji $\mathrm{w}$ obszarach metropolitalnych, przemieszczeniach z miast centralnych do obszarów otaczających (stref podmiejskich) oraz wyludnianiu się obszarów peryferyjnych. W badanym okresie nastąpił znaczący odpływ ludności polskiej za granicę, zwłaszcza ze wschodniej części kraju oraz województwa opolskiego. Pod względem współczynnika przyrostu naturalnego największe jego wartości zaobserwowano w Polsce północno-zachodniej, południowo-wschodniej oraz w strefach podmiejskich większych miast, gdzie zanotował największy wzrost $\mathrm{w}$ badanym okresie. Niemniej jednak, niski poziom dzietności, w większości powiatów nie gwarantował zastępowalności pokoleń. Efektem zmian w natężeniu i kierunkach migracji oraz zróżnicowania przyrostu naturalnego wraz z falowaniem wyżów i niżów demograficznych jest szybsze starzenie się obszarów do niedawna uważanych za młodsze demograficznie (czyli Polski północnej i zachodniej) oraz terenów zurbanizowanych. Następują także zmiany w zasobach siły roboczej z coraz większą ich koncentracją (zwłaszcza ludności w wieku mobilnym) w obszarach metropolitalnych. Typologia struktury wieku ludności wykonana metodą typografów wykazała dużą polaryzację przestrzenną pomiędzy relatywnie młodszymi powiatami rozmieszczonymi na terenie województw małopolskiego, podkarpackiego, wielkopolskiego i pomorskiego a województwami Polski środkowej, wschodniej oraz południowo-zachodniej. Kontynuacja trendu depopulacyjnego wynikającego z niskiego przyrostu naturalnego uwarunkowanego niską dzietnością i coraz późniejszym wiekiem zakładania rodzin oraz emigracją ludzi młodych prowadzić będzie do dalszego pogłębiania starości demograficznej wskutek spadku odsetka ludności przedprodukcyjnej, kurczenia się zasobów pracy i wzrostu udziału ludności w wieku emerytalnym. Ponadto, wzrost liczebności i udziałów ludności w wieku poprodukcyjnym w najbliższych latach będzie związany z wchodzeniem w wiek emerytalny licznego pokolenia wyżu powojennego, co spowoduje niekorzystne zmiany obciążenia ekonomicznego pomiędzy ludnością produkcyjną i poprodukcyjną.

\section{LITERATURA}

Bijak J., Kicinger A., Kupiszewski M., Śleszyński P. (współpraca), 2007, Studium metodologiczne oszacowania rzeczywistej liczby ludności Warszawy, CEFMR Working paper, 2, Środkowoeuropejskie Forum Badań Migracyjnych i Ludnościowych, Warszawa, ss. 76; http://www.cefmr.pan.pl/docs/ cefmr_wp_2007-02.pdf.

Długosz Z., 1996, Zróżnicowanie struktury wieku na świecie a metody jej klasyfikacji, „Przegląd Geograficzny” 68(1-2), s. 151-165. 
Długosz Z., 1998, Próba określenia zmian starości demograficznej Polski w ujęciu przestrzennym, „Wiadomości Statystyczne” 3, GUS-PTS, Warszawa, s. 15-25.

Długosz Z., 2001, Próba dynamicznej typologii ruchu ludności w świetle klasyfikacji Webba na przykładzie województwa małopolskiego [w:] Kortus B. (red.), Człowiek i przestrzeń, IGiGP UJ, Kraków, s. 61-70.

Dzieciuchowicz J., 1995, Determinanty demograficzne i spoteczno-ekonomiczne redystrybucji przestrzennej ludności aglomeracji miejskich (przykład aglomeracji łódzkiej), Wydawnictwo Uniwersytetu Łódzkiego, Łódź.

GUS, 2011, Prognoza dla powiatów i miast na prawie powiatu oraz podregionów na lata 2011-2035, http://www.stat.gov.pl/gus/5840_11752_PLK_HTML.htm.

GUS, 2013, Wybrane tablice dotyczące emigracji na pobyt czasowy powyżej 3 miesięcy - wyniki spisu ludności i mieszkań 2011 r., www.stat.gov.pl.

Jakóbczyk-Gryszkiewicz J. (red.), 2011, Regiony miejskie w Polsce. Dwadzieścia lat transformacji, Wydawnictwo Uniwersytetu Łódzkiego, Łódź.

Jakóbczyk-Gryszkiewicz J., 1998, Przeobrażenia stref podmiejskich dużych miast. Studium porównawcze strefy podmiejskiej Warszawy, Łodzi i Krakowa, Wydawnictwo Uniwersytetu Łódzkiego, Łódź.

Kotowska I. (red.), 1999, Przemiany demograficzne $w$ Polsce w latach 90. w świetle koncepcji drugiego przejścia demograficznego, „Monografie i Opracowania” 461, Szkoła Główna Handlowa, Warszawa.

Kurek S., 2008, Typologia starzenia się ludności Polski w ujęciu przestrzennym, „Prace Monograficzne AP” 497, Wydawnictwo Naukowe Akademii Pedagogicznej, Kraków.

Kurek S., 2012, Przemiany demograficzne $w$ Polsce $w$ świetle teorii drugiego przejścia demograficznego w ujęciu przestrzennym [w:] Rączaszek A. (red.), Demograficzne uwarunkowania rozwoju społecznego, „Studia Ekonomiczne” 98, Zeszyty Naukowe Wydziałowe Uniwersytetu Ekonomicznego w Katowicach, s. 217-230.

Kurek S., Lange M., 2013, Zmiany zachowań prokreacyjnych $w$ Polsce $w$ ujęciu przestrzennym, Wydawnictwo Uniwersytetu Pedagogicznego w Krakowie, Kraków.

Lisowski A., Grochowski M., 2007, Procesy suburbanizacji. Uwarunkowania, formy i konsekwencje, opracowanie przygotowane na zlecenie Ministerstwa Rozwoju Regionalnego, Warszawa.

Słodczyk J. (red.), 2011, Procesy suburbanizacji w wybranych miastach Polski, „Studia Miejskie” 3, Wydawnictwo Uniwersytetu Opolskiego, Opole.

Sobotka T., 2008, The diverse faces of the Second Demographic Transition in Europe, „Demographic Research” 19, s. 171-224; www.demographic-research.org.

Sytuacja Demograficzna Polski, Raport 2011-2012, 2012, Rządowa Rada Ludnościowa, Warszawa.

Śleszyński P., 2006, Demograficzny wymiar procesów suburbanizacji w Polsce po 1989 roku [w:] Kozłowski S. (red.), Żywiołowe rozprzestrzenianie się miast. Narastajacy problem aglomeracji miejskich w Polsce, Studia nad zrównoważonym rozwojem, t. II, Katedra Ochrony Środowiska KUL, Komitet „Człowiek i Środowisko” przy Prezydium PAN, Białystok-Lublin-Warszawa, s. 105-123. 
Śleszyński P., 2012, Warszawa i obszar metropolitalny Warszawy a rozwój Mazowsza, Trendy Rozwojowe Mazowsza 8, Mazowieckie Biuro Planowania Regionalnego w Warszawie.

Van de Kaa D.J., 1987, Europe’s second demographic transition, „Population Bulletin” 42(1), $59 \mathrm{~s}$.

Van de Kaa D.J., 2003, The idea of a second demographic transition in industrialized countries, ,Japanese Journal of Population” 1(1), s. 42-75.

Van de Kaa D.J., 2004, Is the Second Demographic Transition a useful research concept: questions and answers, „Vienna Yearbook of Population Research” 2, s. 3-10.

Van den Berg L., Drewett R., Klaassen L.H., Rossi A., Vijverberg C.H.T., 1982, Urban Europe. A Study of Growth and Decline, Pergamon Press, Oxford.

Winiarczyk-Raźniak A., Raźniak P., 2012, Migracje wewnętrzne ludności w polskich obszarach metropolitalnych u progu XXI wieku, Wydawnictwo Uniwersytetu Pedagogicznego, Kraków.

Zborowski A., 2005, Przemiany struktury spoteczno-przestrzennej regionu miejskiego wokresie realnego socjalizmu transformacji ustrojowej (na przykładzie Krakowa), IGIGP UJ, Kraków.

\begin{abstract}
Contemporary demographic processes in Poland can be seen in the context of the process of suburbanisation leading to concentration of the population in the outer metropolitan areas and in terms of the theory of the second demographic transition, leading to a decline in fertility rates below the replacement rate. The aim of this study is to present contemporary demographic changes in Poland in spatial terms at the beginning of the twenty-first century, particularly in light of the changes between the two national censuses in Poland (in 2002 and 2011), supplemented by the current statistics from the Local Data Bank of Central Statistical Office in Poland. The following issues were investigated: population growth, net migration, natural increase and changes in the age composition of the population. A demographic typology of spatial units (districts) by J.W. Webb was conducted as well as typology of the age structure of the population by the typograph method. The analysis showed a high spatial polarization of demographic processes running between metropolitan and peripherals.
\end{abstract}

KEYWORDS: demographic changes, migration, natural increase, age composition, spatial pattern, suburbanization, Poland 